\title{
Modernising the Constitution: British Territories and Foreign Relations Act: Part 2
}

\author{
Graham McBain ${ }^{1,2}$ \\ ${ }^{1}$ Peterhouse, Cambridge, UK \\ ${ }^{2}$ Harvard Law School, USA \\ Correspondence: Graham McBain, 21 Millmead Terrace, Guildford, Surrey GU2 4AT, UK. E-mail: \\ gsmcbain@aol.com
}

Received: November 8, 2021

Accepted: January 6, 2022 Online Published: January 12, 2022

doi:10.5539/ilr.v11n1p162

URL: https://doi.org/10.5539/ilr.v11n1p162

\section{INTRODUCTION}

Part 1 of this article looked at consolidating c. 150 pieces of legislation relating to foreign affairs into one British Territories and Foreign Relations Act ('BTFRA'). This part, Part 2, looks at placing various Crown prerogatives concerning foreign affairs into the same Act.

Why? Well, the problem is the same as with all Crown prerogatives. As noted in a previous series of articles, at least, $85 \%$ of Crown prerogatives are obsolete. Indeed, in many cases, they have been so for centuries. In the case of those that remain, they are (often) expressed in obscure and uncertain fashion. An amalgam of caselaw and a casebook analysis (sometimes, of scant merit). Further, this material does not reflect modern realities. Especially, the fact that, today, the sovereign has only a titular role and it is Parliament which controls the apparatus of government - as well as the civil servants which manage the same. In short, the law - this legal fiction - is wholly out of kilter with the factual truth ${ }^{1}$ which is not a good thing. Such impedes the development of English law.

\section{In conclusion, this Part concludes the rationale for consolidating legislative and common law material relating to British territories ${ }^{2}$ and foreign relations into a BTFRA. It is not difficult.}

\section{LEGAL TEXTS \& CROWN PREROGATIVES}

Part 1, section 2, refers to various legal texts of particular note when considering British territories and foreign affairs. These are also referred to in the footnotes to this article (which footnotes refer to the texts stated in Part 1, save where otherwise provided). ${ }^{3}$ As for Crown prerogatives which especially relate to foreign affairs, from the Norman Conquest (1066) at least (indeed, before), the Crown has claimed the prerogative to conduct foreign relations (the art of diplomacy). ${ }^{4}$ Such is unsurprising since the Normans and their successors had extensive land and titular possessions on the Continent which they were required to maintain and defend. Something that only ended with the loss of Calais in the 1558 in the reign of Queen Mary (1553-8). Various Crown prerogatives still derive from the common law. That is, by virtue of judicial recognition as opposed to legislation. It is fitting and appropriate that all Crown prerogatives should now be in statutory form. Not least, to clarify their nature and extent. And, to subject them to the review of Parliament. The following Crown prerogatives in respect of foreign affairs are now considered:

- Diplomacy. The Crown prerogative to conduct diplomacy;

- $\quad$ Treaties. The Crown prerogative to enter into treaties;

\footnotetext{
${ }^{1}$ As Chalmers (in 1922), n 15, p 122, put it 'At the present day there is a curious divergence between the law and the practice of the constitution as regards the prerogative. Prerogative acts are done in the name of the Crown, and the executive government is carried on in the name of the Crown. But the prerogative is no longer the personal prerogative of the king. All public acts are done by the Crown on the advice of ministers of the Crown. The privileges arising out of the prerogative are therefore the privileges of the executive, and as ministers are dependent on the House of Commons, that House has now obtained control over what was formerly the peculiar province of the Crown. As Mr Lowell puts it [Chalmers referred to Lowell, Government of England [1908], p 13)] with slight exaggeration 'by leaving the prerogative substantially untouched by law, and requiring that it should be wielded by ministers responsible to them, the Commons have drawn into their own control all the powers of the sovereign that time has not rendered obsolete.'

2 i.e. British domestic territories (the Channel Islands and Isle of Man) and British overseas territories (BOT).

${ }^{3}$ Of particular use, are legal texts by Blackstone (1765-9), Chitty (1820), Halsbury, Laws (1909), Wade (1931) and Bradley (2018, the continuation of Wade). They indicate the altering historical position from the legal perspective of the prerogatives discussed in this article.

${ }^{4}$ E Satow, A Guide to Diplomatic Practice (1 $\left.{ }^{\text {st }} \mathrm{ed}, 1917\right), \mathrm{p} 1$ defined diplomacy as follows: 'Diplomacy is the application of intelligence and tact to the conduct of official relations between the governments of independent states, extending sometime to their relations with vassal states.' See also Walker, n 78 (diplomacy) 'The art of conducting international negotiations. Modern diplomacy dates from the development of permanent missions from one country to another, which began in the fifteenth century.'
} 
- $\quad$ Ambassadors \& other Diplomats. The Crown prerogative to appoint UK ambassadors, consuls and other diplomats. Also, to receive foreign diplomats and to dismiss the same;

- $\quad$ Passports. The Crown prerogative to issue, refuse, impound and revoke passports;

- Divestment of Nationality. The Crown prerogative to divest a UK citizen (British subject) of nationality;

- $\quad$ Territory. The Crown prerogative to acquire foreign territory (including by way of annexation). Also, to cede (i.e. give up) territory;

- $\quad$ Foreign States. The Crown prerogative to recognise foreign states.

At the outset it may be noted that foreign relations have, since the $17^{\text {th }}$ century, been conducted by the Foreign Office - although that title has not been used as such since then and has undergone change. ${ }^{5}$ Today, it is called the Foreign and Commonwealth Development Office ('FCDO'). Although the above Crown prerogatives could be inserted in a Crown Act or a Government Act, it may be appropriate that they be placed in a BTFRA since they all relate to the conduct of activities with foreign countries (nations). Moreover, it is important that these prerogative powers now be clearly stated in legislation and made subject to the control of Parliament. ${ }^{6}$

It may also be noted that there has been little early legal analysis on the Crown prerogatives referred to in this article. This applies to diplomacy in general, unlike on the continent. Thus, the first English text of any note, Satow's A Guide to Diplomatic Practice (1917), noted that - whereas the expression 'diplomatic body' first arose in Vienna about the middle of the $18^{\text {th }}$ century - the earliest use of such an expression in England was not until $1787 .^{7}$

\section{In conclusion, all Crown prerogatives in respect of foreign relations should now be in a statutory form. 3. CROWN PREROGATIVE - DIPLOMACY}

(a) Historical Position

The Crown has the prerogative to conduct diplomacy on behalf of the realm. Thus, Blackstone (writing in 1765) in his Commentaries on the Laws of England (1765-9) stated:

With regard to foreign concerns [relations], the king is the delegate or representative of his people... What is done by the royal authority, with regard to foreign powers, is the act of the whole nation: what is done without the king's concurrence is the act only of private men.

Chitty (in 1820) stated:

With respect to foreign states and affairs, the whole majesty and power of his dominions are placed in the hands of the king, who as representative of his subjects possesses discretionary and unlimited powers. In this capacity [HM] has the sole right to send ambassadors and other foreign ministers and officers abroad, to dictate their instructions, and prescribe rules of conduct and negotiation. [HM] alone can legally make treaties, leagues and alliances with foreign states... ${ }^{9}$ The constitution has made the king the delegate or representative of the people, with regard to foreign affairs; and has invested $\mathrm{HM}$ ] with the supreme exclusive power of managing them... ${ }^{10}$

Halsbury, Laws of England (in 1909) stated:

By the law of the English constitution the Crown acts as the delegate or representative of the nation in the conduct of foreign affairs, and what is done in such matters by the royal authority is the act of the whole nation, and

binding, in general, upon the latter without further sanction. The Crown, therefore, enjoys the sole right of appointing ambassadors, diplomatic agents, consuls and other officers, through whom intercourse with foreign nations is conducted, and of receiving those of foreign states, of making treaties, declaring peace and war, and

\footnotetext{
${ }^{5}$ The term 'foreign office' [department] dervies from 1782. In 1968 it became the Foreign and Commonwealth Office (the Commonwealth Office as the Commonwealth Relations Office had merged with the Colonial Office in 1966) and, from 2012, the Foreign, Commonwealth and Development Office (FCDO). For the foreign and colonial offices in 1909, see Halsbury, Laws (1909), vol 7, pp 86-7. Cf. Wade (in 1931), n 16, p 199 'The [SS] for Foreign Affairs presides over the department designated the Foreign Office.'

${ }^{6}$ Munro, n 24, p 278 'To sum up, the exercise of prerogative powers is imperfectly subject to parliamentary control...'. Ibid, p 291 'There must be some legal powers for the regulation of the civil service, the control of the armed forces, and the conduct of foreign policy. But there would be several advantages in replacing the existing prerogatives with statutory powers, such as the government more usually acts under. If that were done, the purpose and extent of the powers could be clearly set out, whereas much of the law concerning the prerogative is obscure and derived from ancient procedures.'

${ }^{7}$ Satow, $\mathrm{n} 4$ (this article), p 3. The earliest English use of the word 'diploma' (a document by which a privilege is conferred) is asserted by Satow to have been in 1645. Ibid. For general texts on diplomacy, see JC Clarke, British Diplomacy and Foreign Policy 1782-1865: The National Interest (1989); J Black, A History of Diplomacy (2011) and ECG Murray, Embassies and Foreign Courts. A History of Diplomacy (1856).

${ }^{8}$ Blackstone, $\mathrm{n} 31$, vol 1, p 245. Citation of this is longstanding, e.g. T Smith, De Republica Anglorum (trans. M Dewar, written 1562-5, pub CUP 1982), p 85 'the king or queen, has absolutely in his power the authority of war and peace, to defy what prince it shall please him, and to bid him war [i.e. challenge him to war], and again to reconcile himself and enter into league [i.e. peace treaty] or truce with him at his pleasure or the advice only of his privy council.' (spelling modernised)

${ }^{9}$ Chitty, n 11, p 6.

${ }^{10} \mathrm{Ibid}, \mathrm{p} 40$.
} 
generally of conducting all foreign relations. Such matters are intrusted in general to the absolute discretion of the sovereign, acting through the recognised constitutional channels upon the advice of the cabinet or the Secretary of State ['SS'] for Foreign Affairs, unfettered by any direct supervision, parliamentary or otherwise. An indirect

means of control is, however, supplied by the customary or conventional law of the constitution relating to the cabinet system, the doctrine of ministerial responsibility, and the consequent fear of loss of public office or, perhaps, impeachment. Moreover, it is recognised as a constitutional maxim or convention that declarations of peace and war, and the conduct of foreign relations, must be in conformity with the wishes of Parliament, and in certain cases treaties require special parliamentary sanction. ${ }^{11}$

Wade (in 1931) stated:

The king is the sole representative of the nation in international dealings; it is his prerogative to make treaties; to cede territory; to make war and peace; to recognise the status of a foreign country or of its government (that is, to decide whether or not to recognise a new State as a sovereign independent State or the persons in control of an old or new State as its official government); to appoint representatives of his own country abroad and to receive the representatives of other States at his court. ${ }^{12}$

Anson (in 1935) stated:

No person or body save the king, by his ministers or his accredited representatives, can deal with a foreign state so as to acquire rights or incur liabilities on behalf of the community at large...The prerogative of the Crown in this respect is exercised, subject always to the collective responsibility of the cabinet, through one of [HM's] principal [SS], to whom is entrusted the business of communicating with the representatives of foreign states in this country, and with our own representatives in other communities. ${ }^{13}$

As can be seen, from 1765-1935, the tone of legal writers was to affirm the sole responsibility of the sovereign in the conduct of foreign relations. However, from Anson, there is emphasis on the reality of the situation. That is the prerogative is, in fact, exercised by the foreign minister, who is responsible to the cabinet (and to Parliament). This process has continued (greatly) during the course of the $20^{\text {th }}$ century. Thus, Munro noted in 1999:

as with acts involved in the negotiation of treaties or the control of the armed forces...the sovereign has no part to play at all, but the powers are purportedly exercised in his or her name. Thus, as to the largest class of prerogatives, the monarch is little more than a cypher. ${ }^{14}$ (italics supplied)

One would (wholly) agree. The sovereign no longer has an executive function in the conduct of UK diplomacy. This is not to say that the sovereign - as formal Head of State - does not have a formal role. She does, as Bradley (in 2018) noted:

Many formal acts of government require her participation. State documents may require her signature, and she receives copies of all major government papers, including reports from ambassadors abroad and their instructions from the Foreign Office...The Queen gives frequent audiences...[to] visiting ministers from the Commonwealth, receives foreign diplomatic representatives... She receives visits to this country by the heads of foreign states and makes state visits overseas... ${ }^{15}$ (italics supplied)

\section{(b) $\underline{\text { Reform }}$}

In conclusion, the legal fiction is that the Crown is responsible for the conduct of UK diplomacy. Indeed, not just the Crown in the sense of the body politic; very much so qua sovereign (i.e. in the body natural). Yet, today, it is clear that ministers - in particular the FCDO minister - are responsible for the conduct of foreign affairs (diplomacy) on behalf of the UK. Not the sovereign in person (i.e. the Crown in the body natural). Nor the Crown in the body politic. The legal fiction being the opposite, the result is confusion. Also, an increasingly convoluted (twisted) and specious logic having to be employed in legal cases. ${ }^{16}$ Thus, it is asserted that the reality should be stated in a BTFRA. In particular,

\footnotetext{
${ }^{11}$ Halsbury, Laws (1909), vol 6, pp 427-8. Ibid, p 375 para 550 'the conduct of foreign affairs... are intrusted solely to him and his ministers'.

12 Wade, n 16, pp 67-8.

${ }^{13}$ Anson, n 18, vol 2, pt 2, p 131-2. He continued 'The [SS] has certain formal duties, such as the presentation of the representatives of other powers to the sovereign: he is also the channel of communication between individuals or departments of government and foreign countries in any matter in which the intervention of a foreign government may be sought; but the most serious part of his business consists in framing and carrying out a policy for this country in relation to other countries.'

${ }^{14}$ Munro, n 24, p 269. Bradley (in 2018), n 26, p 260 'The conduct of foreign affairs by the government is carried on mainly by reliance on the prerogative.' Halsbury, Laws ( $\left.5^{\text {th }} \mathrm{ed}\right)$, vol 20 'Foreign affairs [i.e. diplomacy].... are conducted in her name...However, in accordance with the conventions or principle of constitution monarchy, the monarch's pubic legal acts and duties are exercised in accordance with ministerial advice.'

${ }^{15}$ Bradley, n 26, p 245.

${ }^{16}$ The specious logic is that the conduct of foreign relations is the responsibility of the Crown (i.e. ministers and their civil servants) who are responsible to...the Crown (i.e. the sovereign whether in the body personal or politic). The reality is that the conduct of foreign relations is the responsibility of ministers (and their civil servants) who are (both) responsible to Cabinet and to Parliament.
} 
- That it is the FCDO which is (legally) responsible for the conduct of the UK's foreign relations - save where legislation provides otherwise. Not the sovereign or the Crown in the body politic;

- That the Foreign Minister (and the FCDO) is responsible to cabinet and to Parliament. Not to the sovereign or to the Crown in the body politic. Thus, a BTFRA will set out a clear legal 'chain' of accountability.

Further, on a more practical note, it is worth considering whether the time of the sovereign - as formal Head of State, is being well spent and - if not - whether the Foreign Minister and FCDO should take over that role.

- Thus, the sovereign meeting foreign Heads of State from time to time seems a worthwhile activity. Especially Commonwealth Heads of State. However, is it really necessary for her to receive reports from foreign ambassadors abroad and their instructions from the Foreign Office? One would suggest not. A weekly summary surely, would be more sensible (after all, there must be a question whether the sovereign actually reads and assimilates all this material);

- And, is it really necessary for the sovereign to have to accredit (receive) foreign diplomatic representatives? Surely, the appointment, and dismissal, of all of such should be undertaken now only by the Foreign Minister (or delegate) and the FCDO.

In short, would it not be better for the sovereign to spend her time more profitably meeting more Heads of State (especially, Commonwealth ones) - than dealing with the (rather lower level) matter of meeting frequently changing ambassadors?

As it is, although it is stll the legal fiction that the sovereign conducts foreign affairs (which was true to a considerable extent in the time of Elizabeth I (1558-1603), the reality is that the government-and the FCDO especially - is in charge of the same. A BTFRA should state this.

\section{CROWN PREROGATIVE - TREATIES}

\section{(a) Historical Position}

A primary aspect of diplomacy was the conclusion of treaties (agreements) ${ }^{17}$ with foreign States. From the Norman Conquest (1066) until the reign of Queen Anne (1702-14), the sovereign tended to be intimately involved in the same. ${ }^{18}$ Such was (greatly) due to fact that the sovereign had land abroad or claimed sovereignty over the same (such as in Scotland or France). By the time of Queen Mary (1553-8) this was no longer the case. This, as well as Cabinet operating in the absence of the sovereign from 1717 (the reign of the German speaking George I (1714-27), resulted in a continuing decline in the involvement of the sovereign in treaty making. Such is reflected in the progressive statements of legal writers. Thus, Blackstone (in 1765) stated:

It is also the king's prerogative to make treaties, leagues ${ }^{19}$ and alliances with foreign states and princes. For it is by the law of nations essential to the goodness of a league, that it be made by the sovereign power; and then it is binding upon the whole community: and in England the sovereign power, quoad hoc, is vested in the person of the king. ${ }^{20}$

Chitty (in 1820) stated:

$[\mathrm{HM}]$ alone can legally make treaties, leagues and alliances with foreign states... ${ }^{21}$ the king alone may make treaties, a treaty made by him with a foreign power. ${ }^{22}$

From Victorian times, in particular, Parliament took a more active interest in treaty making. Not least because of the financial cost involved with the acquisition of new countries to the Empire. Amos (in 1880) noted:

No prerogative of the Crown is more undisputed than that of taking the initiative in all negotiations with foreign governments, conducting them throughout, and finally completing them by the signature and ratification of a treaty. But a treaty may involve a large expenditure of the national funds, possibly stretching over a period of many years, or obligations of a most onerous and responsible kind, in the performance of which the whole country has the keenest and most direct interest. Thus, while saving the dignity and claims of the royal prerogative, ministers are generally

\footnotetext{
${ }^{17}$ Walker, n 78 (treaties) 'A international agreement normally in written form, passing under various titles (treaty, convention, protocol, covenant, charter, pact, statute, act, declaration, concordat, exchange of notes, agreed minute, memorandum of agreement) concluded between two or more states, or other subjects of international law, intended to create rights and obligations between them and governed by international law... Treaty making power is confined to sovereign states and other international legal person.' The Vienna Convention on the Law of Treaties (Cmnd 4848, 1969) defined a treaty as a written agreement between states governed by international law.', as noted by Barnett, $\mathrm{n} 27$, $\mathrm{p} 114$. See also Halsbury, Laws ( $5^{\text {th }}$ ed), vol 20, para 555 and Constitutional Reform and Governance Act 2010, s 25.

${ }^{18}$ See e.g. Anson, n 18, vol 2, pt 1 (4 $4^{\text {th }}$ ed, 1935), pp 104-8. Also, AB Keith, The King and the Imperial Crown (1936), p 63.

${ }^{19}$ The word 'league' tended to be used as a reference to peace treaties in particular.

${ }^{20}$ Blackstone, n 31, vol 1, p 249. He continued 'And yet, lest this plenitude of authority should be abused to the detriment of the public, the constitution (as was hinted before) hath interposed a check, by the means of Parliamentary impeachment, for the punishment of such ministers as advise or conclude a treaty, which shall afterwards be judged to derogate from the honour and interest of the nation.'

${ }^{21}$ Chitty, n 11, p 6.

${ }^{22}$ Ibid, p 170.
} 
not adverse to making Parliament share, from a very early moment in the course of the negotiations, in the responsibility attaching to the final settlement in which they may result. ${ }^{23}$

The practice, therefore, became one of Parliament being notified of treaties entered into by the government in power and consenting to the same. Halsbury, Laws of England (in 1909) stated:

Treaties or contracts between nation and nation, which are also known under the name of conventions, declarations, protocols, or general acts, are usually agreed upon by agents appointed by the treaty-making authority in either State, the English agents for such purposes being appointed by the Crown. The great seal of the [UK] is to be used for sealing all treaties with foreign princes and States. Treaties thus concluded are in general binding upon the subject without express parliamentary sanction; but the previous consent of, or subsequent ratification by, the legislature is legally necessary to their validity in certain cases. Thus, though treaties relating to war and peace, the cession of territory, or concluding alliances with foreign powers are generally conceded to be binding upon the nation without express parliamentary sanction, it is deemed safer to obtain such sanction in the case of an important cession of territory. And where taxation is imposed or a grant from the public funds rendered necessary, or where the private rights of the subject are interfered with by a treaty concluded in time of peace, it is apprehended that the previous or subsequent consent of Parliament is in all cases required to render the treaty binding upon the subject and enforceable by officers of the Crown. But where the treaty is made to put an end to war, or, possibly, to prevent war, on public grounds and for the public safety, it is doubtful whether the sanction of Parliament would be always required... ${ }^{24}$ (italics supplied)

Wade (in 1931) stated:

Closely allied to the executive power of making war and declaring peace is the prerogative of treaty making. No one but the king can bind the community by treaty ${ }^{25}$ At first sight the treaty-making power appears to conflict, with the constitutional principle that the king by prerogative cannot alter the law. In practice it must be remembered that treaties are concluded on the advice of ministers, and that those ministers will normally be in a position to command a majority in Parliament... ${ }^{26}$

De Smith (in 1998) stated:

Treaties are international agreements...27 Any such international instrument to which the [UK] is a party binds the [UK] in international law. Normally it becomes binding only when ratified by the executive, though some agreements have been effected upon signature, and a few have effect only when approved by Act of Parliament. ${ }^{28}$ The treaty itself may specify when and in what circumstances it shall come into effect. It is a constitutional usage, and possibly a binding convention, to lay the texts of international agreements before both Houses of Parliament for twenty- one days before ratification, if ratification is required. The conclusion of a treaty is an act of State and an exercise of the royal prerogative, even though the Queen has not played a formal role in the matter (for example, by granting full powers to plenipotentiaries to negotiate and sign on her behalf, and by ratifying the treaty under great seal); the prerogative, or part of it, may be exercised by the [SS] for Foreign and Commonwealth Affairs as her delegate..$^{29}$

Phillips and Jackson (2001) stated:

\footnotetext{
${ }^{23}$ Amos, $\mathrm{n} 73, \mathrm{p} 388$. He referred to the negative consequences of the non-involvement of Parliament. 'It is a bare fact that during the progress of the British diplomatic movements which terminated in the Treaty of Berlin of 1878, or more properly in the Afghan war of that year, Parliament never had an opportunity of expressing its mind on any one of the important and complicated engagements to which the country was being committed, or upon the policy of the war on the North-West frontier of India. The subjects were indeed over and over discussed in Parliament, but always subsequent to irreparable action having been taken by the Government.'

${ }^{24}$ Halsbury, Laws (1909), vol 6, pp 439-40. The wording in italics is the very case where, today, a treaty would almost certainly require the consent of Parliament!

${ }^{25}$ Wade, n 16, also noted, p 204 'The term, treaty, is unfortunately used very loosely of all international engagements in written form, but it must be remembered that such engagements are as capable of classification as documents in municipal law, e.g., it would be incorrect to describe the effects of a simple contract in writing and a conveyance as identical, so a commercial agreement with another State differs from a treaty of cession, or from a law-making treaty.'

${ }^{26}$ Ibid. AB Keith, The Constitution of England from Queen Victoria to George VI (1940), vol 2, p 133 'the sole right to make treaties is vested in the Crown in its executive aspect. The most formal method is by negotiations carried out by plenipotentiaries under full powers issued by the king under the great seal, on the authority of a sign-manual warrant countersigned by the Foreign Secretary, and ratified by the king on like advice.' He also noted that: 'The Munich agreement, Sept 29, 1938, is signed by the [PM] without any reference to royal authority, and is unique. The guarantee of Czechoslovakia equally rested on his promise, repeated in the [House of] Lords on several occasions, and explained by Sir T Inskip, Oct 1938.'

${ }^{27}$ De Smith continued, n 23, p 146 'Such agreements may be called treaties, conventions, covenants, pacts, charters, agreements, protocols, even statutes, declarations or exchanges of notes. They may be bilateral or multilateral; they may be concluded between heads of State, or between governments, or between governments and international organisations. They may deal with political, defence, economic, legal, social or cultural matters. Any such international instrument to which the [UK] is a party binds the [UK] in international law.'

${ }^{28}$ Ibid, p 148 also stated 'With few exceptions, internationally binding obligations still need to be given legislative effect if they are to be enforced as law by the courts of this country. They may be given such effect if their provisions (or some of them) are incorporated in or scheduled to an Act of Parliament, or in a statutory instrument (for example an [OIC]) made under the authority of an Act of Parliament.'

${ }^{29}$ Ibid, p 147.
} 
The treaty-making power is an executive power which in British constitutional law is vested in the Crown. A treaty is analogous to a contract between states. Its binding force is a matter of international law. The negotiations are conducted by the agents of the Crown e.g. the Foreign Secretary or a diplomatic representative... ${ }^{30}[$ treaties] are usually made subject to ratification by the Crown under the great seal. Treaties are acts of State, and do not in general require Parliamentary sanction. Where treaties require ratification by the Crown (i.e. treaties between Heads of State, but not commercial or technical agreements at official level) it has been the practice since 1924 to lay them when signed before both Houses of Parliament for 21 days before they are ratified ('the Ponsonby Rule'). It is open to argument whether this practice may be regarded as a constitutional convention. It has also been described as a 'socalled rule...no more than a self denying ordinance on the part of the government; on occasions it has been waived or modified if expediency requires a treaty to be ratified more hurriedly.' On important treaties the government initiates a discussion; otherwise the Opposition may ask for a discussion. ${ }^{31}$

In conclusion - as with diplomacy (see 3), the position with respect to UK treaty making has evolved over time. At first, it was the prerogative in person. Today, it is wholly under the control of government. Especially, the FCDO. In the $20^{\text {th }}$ century, Parliament was increasingly involved in oversighting the acts of the government in respect of treaty making, with the laying of the treaty before Parliament before ratification (when the latter was required).

\section{(b) Position Today - Ratification}

Today, the oversight of treaties by Parliament has been provided for in legislation Thus, a prior article has noted that the Constitutional Reform and Governance Act 2010 contains provision for treaties to be laid before Parliament ${ }^{32}$ viz. the following sections:

$\begin{array}{ll}\text { s } 20 & \text { (treaties to be laid before Parliament before ratification), } \\ \text { s } 21 & \text { (extension of } 21 \text { day sitting period), } \\ \text { s } 22 & \text { (s 20 not to apply in exceptional cases), } \\ \text { s } 23 & \text { (s 20 not to apply to certain descriptions of treaties), } \\ \text { s } 24 & \text { (explanatory memoranda), } \\ \text { s } 25 & \text { (meaning of 'treaty' and 'ratification'). }\end{array}$

Barnett (in 2020) summarised their effect:

The Labour Government's 2007 green paper, The Governance of Britain, stated that the procedure for parliamentary scrutiny of treaties should be formalised. The [Act, s 20] provides that a treaty is not to be ratified unless a minister has laid a copy of the treaty before Parliament and neither the House of Commons nor the House of Lords has resolved, in a period of 21 sitting days, that the treaty should not be ratified. If the [HC] has resolved [that the treaty not be ratified] (whether or not the [HL] has also resolved), the treaty may still be ratified if a minister lays before Parliament a statement of reasons why the treaty should be ratified and a period of 21 sitting days has expired without the $[\mathrm{HC}]$ resolving that it should not be ratified. If the $[\mathrm{HL}]$ but not the $[\mathrm{HC}]$ resolves that the treaty should not be ratified, the treaty may be ratified if a minister has laid before Parliament a statement, indicating, with reasons, that he or she is of opinion that it should be ratified. ${ }^{33}$

However, it should be noted that this legislation does not affect the principle that a ratified treaty is not enforceable in domestic law without an Act of Parliament. ${ }^{34}$

\section{(c) Reform}

Treaties will continue to be made. However, in a modern democracy, there should be Parliamentary oversight over most treaties. ${ }^{35}$ There is long established precedent for this; by 1880 , Amos noted the:

habitual practice of submitting all important treaties to the judgment of the Houses before signature or ratification. ${ }^{36}$

\footnotetext{
${ }^{30} \mathrm{OH}$ Phillips \& P Jackson, Constitutional and Administrative Law ( $8^{\text {th }}$ ed, 2001), pp 326-7.

${ }^{31}$ Ibid, p 327. They also noted 3 classes of treaty which required confirmation by Parliament, those: (a) expressly made subject to confirmation by Parliament; (b) involving an alteration of English law or taxation; (c) affecting private rights. Ibid, pp 327-9.

${ }^{32}$ McBain, n 1 (Parliament). p 180.

${ }^{33}$ Barnett, n 27, p 114. See also Bradley (in 2018), pp 261-2.

${ }^{34}$ Bradley, n 26, p 262. See also Halsbury, Laws ( $5^{\text {th }}$ ed), vol 20, para 556 'Treaties are not directly applicable in the [UK], and the courts do not have any inherent power to enforce treaty rights or obligations. Where the purpose and intended effect of a treaty necessitates legal changes in the [UK], these must be implemented by Act of Parliament. The courts may, however, rely upon a treaty as an aid to construction in their interpretation of domestic statutory provisions.'

${ }^{35}$ Phillips \& Jackson (in 2001), n 30 (this article), p 328, noted the 'increasing tendency' of the Crown to 'keep Parliament informed and to invite expressions of opinion before the Crown finally commits itself.'

${ }^{36}$ Amos, $n$ 73, p 389. He referred to an abuse of the 'prerogative by converting the right of secret diplomacy, which only exists and ought to be cherished on behalf of grave national crises when the last interests of the nation are at stake, into a means, fortunately happening to be at their disposal, for evading the legitimate scrutiny of Parliament in respect of matters in which the country has the profoundest interest, and for
} 
As with diplomacy, it is suggested that provision should be made for the following in a BTFRA, reflecting the evolving historical position and caselaw:

- $\quad$ Which Ministry Accountable. The FCDO should be acknowledged as the ministry which is primarily responsible for treaty making - save, where legislation provides otherwise;

- $\quad$ Crown Prerogative to Make Treaties. Any Crown prerogative to make treaties should be abolished. As it is, it has long been the position that the sovereign, in person, has no part to play in the making of treaties; ${ }^{37}$

- $\quad$ Ratification. Treaties are ratified according to the Constitutional Reform and Governance Act 2010, ss 20-5 (these sections should be set out in a BTFRA); ${ }^{38}$

- Enforceability. No ratified treaty is enforceable under domestic law without being placed in an Act of Parliament. ${ }^{39}$ However, provision should be made for more minor treaties to be in a SI - this, to extend the range of 'treaties' that pass under the srutiny of Parliament;

- $\quad$ Justiciable. The decision to make - or ratify or denounce - a treaty (or not) should not be justiciable. ${ }^{40}$ These are political decisions and legislation and the courts should (it is asserted) clarify the boundaries between the legal and political worlds by establishing what are 'political' decisions or not. If political, the same should not be justiciable or else the courts will start to encroach upon the (wise) separation of powers.

In conclusion, the Crown prerogative to make treaties should be abolished and statutory provision made. The primary ministry responsible for treaty making should be the FCDO.

\section{CROWN PREROGATIVE - APPOINTMENT OF UK DIPLOMATS}

As Walker noted, diplomatic representation occurred from a very early date.

Diplomatic representation of one state at the capital of another is known from a very early date and was highly developed among the Greeks and at Rome, though only in the form of envoys, not permanent embassies. The Emperors at Byzantium, the Popes, and Charlemagne, and his successors all sent representatives to many rulers. Early on the popes sent personal representatives to the various national churches, sometimes for long periods, and princes began to have their interests represented at Rome. Venice was the first state to create a diplomatic service, with ambassadors in all the main capitals in the sixteenth century. Thereafter France and Spain established continuous representation at the main courts and Henry VIII [1509-47] sent envoys on special missions; Elizabeth [I, 1558-1603] had almost continuous representation in Paris... In the seventeenth century representatives became divided into recognised grades. The Congress of Vienna [1815] distinguished (a) ambassadors, legates and nuncios; (b) ministers plenipotentiary and envoys extraordinary; and charges d'affaires accredited to foreign ministers. Later the category of ministers resident was provided for, ranking between (b) and (c)...Ambassadors are considered the special representatives of the heads of their states. ${ }^{41}$

(a) UK Ambassadors

Only the Crown has the power to appoint UK ambassadors (in older times, the word was, also, spelt 'embassadors') 42 and to receive (accredit) foreign ambassadors. However, the law on this has been scant. Not least, since England was later than others in establishing embassies. Coke (writing c. 1628, but not published until 1641) dealt with the subject of ambassadors. However, he mainly cited civil and ecclesiastical material. ${ }^{43} \mathrm{He}$ noted that ambassadors were formerly called oratores, then legates (legati) or agents/messengers (nuntii). Finally, ambassiatores (embassiotores). Coke also stated:

\footnotetext{
the right conduct of which the House of Commons is responsible to its constituents, and both Houses of Parliament to the country at large and to posterity.'

${ }^{37}$ Munro, n 24, p 269 'as with acts involved in the negotiation of treaties or the control of the armed forces, for example, the sovereign has no part to play at all, but the powers are purportedly exercised in his or her name. Thus, as to the largest class of prerogatives, the monarch today is little more than a cypher.'

${ }^{38}$ At present, I have placed them in a Parliament Act, see n 1, p 180.

${ }^{39}$ Bradley, n 26, p 262. Also, p 271, citing $R$ v Home Secretary, ex $p$ Brind [1991] 1 AC 48.

${ }^{40}$ Ibid, p 271, following Blackburn v Attorney-General [1971] 1 WLR 1037.

${ }^{41}$ Walker, n 78. (diplomatic representation and privileges). For early texts on ambassadors, see Sweet, n 36, vol 1, pp 599-600. For the derivation of the word 'ambassador' and the categories of diplomat, see Satow, $\mathrm{n} 4$ (this article).

${ }^{42}$ See e.g. Blackstone, n 31, vol 1, p 246. For early texts on diplomatic practice, see Sweet, n 36, vol 2. Walker, n 78 (ambassador) 'A person appointed by the sovereign or other head of state, to represent that person at a foreign court and to act as the recognized channel for foreign communications with the foreign government, negotiations, complaints and representations. An ambassador is the highest rank of diplomatic representative and they were originally accredited only for monarchies, but were later sent out to republics, and now ambassadors are normally sent to all countries with which the sending country has diplomatic relations.'

${ }^{43}$ Oddly, perhaps, this was contained in volume 4 which dealt with courts. See Coke, n 29, vol 4, pp 152-6 ('And incidentally of the office, authority and privilege of ambassadors; and of leagues, treaties, and truces).'
} 
at this day there could be no ambassador without letters of credence of his sovereign, ${ }^{44}$ to another that had sovereign authority...ambassadors ought to be kept from all injuries and wrongs, and by the law of all countries, and of all nations they ought to be safe and sure in every place, in so much as it is not lawful to hurt the ambassadors of our enemies and herewith agrees the civil law... But if a foreign ambassador being prorex ${ }^{45}$ commits here any crime, which is contra ius gentium, as treason, felony, adultery, or any other crime which is against the law of nations, he loses the privilege and dignity of an ambassador as unworthy of so high a place, and may be punished here as any other private alien, and not to be remanded [i.e. sent back] to his sovereign but of curtesy [goodwill]... ${ }^{46}$ (spelling modernised)

Blackstone (in 1765) stated:

The king therefore, considered as the representative of his people, has the sole power of sending ambassadors to foreign states, and receiving ambassadors at home... The rights, the powers, the duties, and the privileges of ambassadors are determined by the law of nature and nations, and not by any municipal constitutions. ${ }^{47}$

Chitty (in 1820) stated:

The constitution has vested in the king the sole power of sending ambassadors, consuls, and other ministers abroad, and receiving ambassadors from foreign states. These need not be appointed by letters patent or by any other particular instrument, though they universally receive on their appointments some document evidencing their right to fill the situation assigned to them; and the consul is generally, if not always, appointed by a commission directed to him from the king. ${ }^{48}$

Maitland (in 1887-8) stated:

the power to send and receive ambassadors deserves notice. It has some important legal effects. An ambassador accredited to the Queen occupies a very privileged place, To a large extent he, his family, his suite and his servants, are placed outside the ordinary civil and criminal law of the country, it being unlawful and criminal to arrest them, or to exercise any compulsory process against them. In this matter the English courts receive what they consider to be the best doctrines of international law. But the arrest of an ambassador, or any servant of his, publicly registered as such, is punishable under a statute of 1708 (7 Anne, c 12 [rep]). That statute was passed in consequence of the ambassador of Peter the Great [of Russia] having been arrested for debt, and it denounces a very severe punishment against those who are guilty of the like acts in the future. The exact limits of the punishment are not in all respects well defined, and are, I think, best discussed as a topic of international law. ${ }^{49}$

Wade (in 1931) stated:

the king is the sole representative of the nation in international dealings; it is his prerogative to...appoint representatives of his own country abroad and to receive the representatives of other states at his court. ${ }^{50}$

Keith (in 1940) stated:

To the foreign secretary appertains the duty of advising the sovereign as to the appointing of British ambassadors and ministers, and the acceptance of proposed appointments of foreign agents. Ambassadors and envoys extraordinary are accredited by foreign states to the king personally, and he sends letters of credence to foreign sovereigns; ministers resident and charges d'affaires to the [SS] and vice versa... The Foreign Secretary controls the diplomatic service in its various branches both by appointment and transfer, and by standing regulations and correspondence and personal discussion..$^{51}$

\section{(b) Consuls}

Walker (in 1980) noted generally as to consuls:

In the ancient Roman republic the consuls were the two chief magistrates, elected annually for the year. In the later Middle Ages merchants in the commercial towns of Italy, France and Spain used to elect one or more of their number to act as arbitrators in commercial disputes, known as juges consuls or consuls marchands. When merchants from these countries settled in Eastern countries they carried the institution with them. The powers of consuls became extended by treaties between their home countries and the countries where they traded and came to comprise the whole civil and criminal jurisdiction and the protection of the lives, privileges, and property of their countrymen. The institution spread westwards also but in the west the jurisdictional powers of consul decayed from the

\footnotetext{
${ }^{44}$ Hence, the term to 'accredit' an ambassador. Walker, n 78 (accredit) 'To furnish an ambassador or other diplomatic agent with documents and authority which will ensure that he is received and given the credit properly due to him.'

${ }^{45}$ The expression in this context suggest that Coke meant 'duly appointed'.

${ }^{46}$ Coke, n 29, vol 4, pp 152-3.

${ }^{47}$ Blackstone, n 31, vol 1, pp 245-6. See also Coke, n 29, vol 1, 2.329.

${ }^{48}$ Chitty, n 11, p 40. Ibid, p 170 'As the protector of commerce, the king alone possesses the power of appointing consuls.' See also Halsbury, Laws, vol 6 (1909), p 375 para 550 'the conduct of foreign affairs... are intrusted solely to him and his ministers'.

${ }^{49}$ Maitland, n 13, p 426.

${ }^{50}$ Wade, $\mathrm{n} 16, \mathrm{p}$ 68. See also ch 7 where he discusses diplomatic and consular immunity. He also provides an example (in 1931) of the form of ambassadorial appointment under the royal sign manual, see Ibid, pp 418-9.

${ }^{51}$ Keith, n 26 (this article), vol 2, p 130.
} 
seventeenth century as foreigners were brought under the jurisdiction of the local courts. Their functions came to be limited to protecting the commercial interests of their countrymen. They are now agents of states for purposes mainly concerned with commercial and maritime interests of the appointing state...

Consuls are not diplomatic representatives and do not enjoy diplomatic privileges, unless also accredited as charges d'affaires. There are generally recognised four classes of consuls, consuls-general, in charge of several consular districts, consuls, vice-consuls, and agent-consular who may be appointed to exercise consular functions in certain towns...Consuls are appointed by a lettre de provision of the sending state, which is communicated to the head of the host state and an exequatur granted thereon. Vice-consuls and agents consular are appointed by the consul. ..Though they do not enjoy the privileges of diplomatic agents, consular premises are inviolable and exempt from taxation, and consular officers are personally inviolable, immune from local jurisdiction and from taxation, from customs duties and personal services and contributions. Consular office terminates on the death, recall, or dismissal of the consul, withdrawal of the exequatur or war between the appointing and the host state. ${ }^{52}$

As for the consular service in the UK, Anson thought that the commencement of appointing consuls started in 1581 when the Levant Company ${ }^{53}$ obtained a Crown charter enabling them to appoint consuls to, inter alia, administer justice between merchants'in all places in the dominion of the Grand Seignior and in otherLevant Seas. ${ }^{54}$ Halsbury, Laws of England (1909) stated:

The consular service is subordinate to the diplomatic service, the diplomatic representative in the country in which a consular officer is stationed being invested with authority over him, subject to the control of the [SS] for Foreign Affairs. A consular officer shall carry out instructions received from the diplomatic representative, if not inconsistent with general instructions from the Foreign Office.... The ranks in the service are - agent and consul-general; consulgeneral; consul; vice- consul; consular agent; and pro-consul. Agents and consuls-general, consuls-general, consuls, and, in some instances, vice-consuls are appointed by commission from the Crown, and are described as 'His Britannic Majesty's' agent and consul-general' etc. Vice-consuls are not appointed by commission, consular agents, and pro-consuls are appointed by letter of authority issued, with the sanction of the [SS], by a consular officer whose commission authorises him to make such appointments. They are described as 'British' vice-consul etc. ${ }^{55}$

Keith (writing in 1940) noted:

The consular service is under the control of the Foreign Office and of the Overseas Trade department, whose secretary is appointed by the Foreign Secretary and the Board of Trade... They are commissioned by the Crown through the Foreign Secretary...they have no diplomatic status. They do not enjoy therefore the immunities of diplomats, but respect should be paid to their papers, though in civil and criminal matters alike they are subject to local jurisdiction...In the case of British officers those of the rank of consul or of higher rank are appointed by royal commission, and request for their recognition is made through the diplomatic representative of the Crown and is usually accorded by an exequatur; vice consuls if appointed by commission receive like treatment, but others, consular agents and pro-consuls, are recognised less formally, and are appointed by letter from higher

consular officers. ${ }^{56}$

Thus, UK ambassadors, ambassadors and other diplomats are officially appointed by the Crown. However, in reality, the FCDO is responsible for the same. The position in respect of their immunity (civil and criminal) is now regulated by statute and international convention, see 6 ,

\section{CROWN PREROGATIVE - DIPLOMATIC PRIVILEGES (inc IMMUNITY)}

\section{(a) Historical Position}

Blackstone (in 1765) referred to the immunity of a foreign ambassador (while in England and acting as such) from civil prosecution - such as for debt. ${ }^{57}$ Also, from criminal prosecution. He stated:

The rights, the powers, the duties, and the privileges of embassadors are determined by the law of nature and of nations, and not by any municipal constitutions. For, as they represent the persons of their respective masters, who owe no subjection to any laws but those of their own country, their actions are not subject to the control of the private law of that state, wherein they are appointed to reside. He that is subject to the coercion of laws is necessarily

\footnotetext{
${ }^{52}$ Walker, n 78 (consul).

${ }^{53}$ The Levant Company was established in 1592 pursuant to a Crown charter.

${ }^{54}$ Anson, n 18, vol 2, pt 2. The ability to appoint consular courts became subject to the Foreign Jurisdiction Acts from 1843, now consolidated in the Foreign Jurisdiction Act 1890 (still extant) discussed in Part 1 of this article.

${ }^{55}$ Halsbury, Laws (1909), vol 6, pp 434-5.

${ }^{56}$ Keith, n 26 (this article), p 147. See also Anson, n 18, vol 2, pt 2, pp 135-6. He noted that 'The immunities of a consul are of somewhat uncertain extent'. Wade, n 16, p 199 'The conduct of foreign relations involves the collection of information and correspondence on an extensive scale. It also involves the exchange of diplomatic representatives and other agents (consular agents). The former represent the State in its external relations with other States; the latter (consuls) are chiefly concerned with British subjects resident or travelling abroad; matters of commerce, industry and navigation fall within their scope.'

${ }^{57}$ As Blackstone notes, n 31, p 247 there appears to have been no immunity of ambassadors for arrest for debt (or seizure of their goods) until 1708 when a Russian ambassador was arrested. Peter the Great, the Tsar, demanding death for such insolence, an Act was passed (7 Anne c 12, rep). See also Ibid, vol 4, pp 70-1. Also, Coke, n 29, vol 4, p 153, Barnett, n 27, p 112 and Philips \& Jackson, n 30 (this article), p 330.
} 
dependent on that power by whom those laws were made: but an ambassador ought to be independent of every power except by which he is sent; and of consequence ought not to be subject to the mere municipal laws of that nation, wherein he is to exercise his functions. ${ }^{58}$

If he grossly offends, or makes an ill use of his character, he may be sent home and accused before his master; who is bound either to do justice upon him, or to avow himself the accomplice of his crimes. But there is great dispute among the writers on the law of nations, whether this exemption of ambassadors extends to all crimes, as well natural as positive, or whether it only extends to such as are mala prohibita, as coining; and not to those that are mala in se, as murder. Our law seems to have formerly taken in the restriction, as well as the general exemption. For it has been held, both by our common lawyers and civilians, that an embassador is privileged by the law of nature and nations; and yet if he commits any offence against the law of reason and nature he shall lose his privilege: and that therefore, if an ambassador conspires the death of the king in whose land he is, he may be condemned and executed for treason; but if he commits any other species of treason, it is otherwise, and he must be sent to his own kingdom. And these positions seem to be built upon good appearance of reason.

For since, we have formerly shown, all municipal laws act in subordination to the primary law of nature, and, when they annex a punishment to natural crimes, are only declaratory of and auxiliary to that law; therefore to this natural, universal rule of justice embassadors, as well as other men, are subject in all countries; and of consequence it is reasonable that wherever they transgress it, there they shall be liable to make atonement. But, however, these principles might formerly obtain, the general practice of Europe seems not to have adopted the sentiments of the learned Grotius, ${ }^{59}$ that the security of embassadors is of more importance than the punishment of a particular crime. And therefore few, if any, examples have happened within a century past, where an embassdor has been punished for any offence, however atrocious in it's nature. ${ }^{60}$

It seems clear that Blackstone did not agree to an extensive immunity being granted to ambassadors in his time and could see no basis for such in the common law. Chitty (in 1820), for his part, did not deal with ambassadors and to their immunity. ${ }^{61}$ For the position as to their immunity by 1940 , see Keith. ${ }^{62}$

\section{(b) Diplomatic Privileges Act 1964}

The text of this Act still extant is set out in $\mathbf{1 4} .{ }^{63}$ Section 1 is particularly important since it states:

The following provisions of this Act shall, with respect to the matter dealt with therein, have effect in substitution for any previous enactment or rule of law.

As Halsbury, Statutes notes:

This section provides for replacing the previously existing law on the subject of diplomatic privileges and immunities, whether governed by statute or rule of law, by the following provisions of this Act, which gives the force of law to the relevant provisions of the Vienna Convention on Diplomatic Relations (Cmnd 2565)...The Convention came into force on 24 April $1964 .^{64}$

As for the Vienna Convention (the articles of which are contained in a schedule to the Act) they deal, inter alia, with diplomatic premises, tax, archives, correspondence, social security, a diplomat's family etc. In particular, the following articles may be noted in respect of a diplomat's criminal and civil liability.

- Art 29 states: The person of a diplomatic agent shall be inviolable. He shall not be liable to any form of arrest or detention. The receiving state shall treat him with due respect and shall take all appropriate steps to prevent any attack on his person, freedom or dignity;

- Art 31(1) states: A diplomatic agent shall enjoy immunity from the criminal jurisdiction of the receiving State. He shall also enjoy immunity from its civil and administrative jurisdiction, except in the case of: (a) a real action relating to private immovable property situated in the territory of the receiving State, unless he holds it on behalf of the sending State for the purposes of the mission; (b) an action relating to succession in which the diplomatic agent is involved as executor, administrator, heir or legatee as a private person and not on behalf of the sending State; (c) an

\footnotetext{
${ }^{58}$ Blackstone referred to the case of count Gyllenberg (Gyllenborg/Cyllenborg), the Swedish minister to Great Britain in 1716, who plotted to remove George I (1714-27) from the throne in favour of the Jacobite Pretender. Gyllenborg was arrested and his papers seized. See Satow, $\mathrm{n}$ 4 (this article), pp 245-6. Also, Phillips \& Jackson, n 30 (this article), p 331 and JC Barker, The Abuse of Diplomatic Privileges and Immunities (1996).

${ }^{59}$ See H Grotius, The Right of War and Peace (trans, Liberty Fund, 1005), bk 2, ch 18 (of the right of embassage).

${ }^{60}$ Blackstone, n 31, vol 1, pp 246-7.

${ }^{61}$ See Chitty, n 11, p 40.

${ }^{62}$ Keith, n 26 (this article), vol 2, pp 130-3.

${ }^{63}$ This Act repealed the Diplomatic Immunities Restriction Act 1955.

${ }^{64}$ Halsbury, Statutes $\left(4^{\text {th }}\right.$ ed), vol 10(1). It continues 'The High Commissioners of independent Commonwealth countries, members of their staff etc fall under this Act, but the Acts does not cover the privileges and immunities of persons from foreign sovereign States and Commonwealth conferences attending conferences, nor those of international organisations and persons connected therewith, which are governed by the International Organisations Act 1968.' See also Phillips \& Jackson, n 30 (this article), p 331.
} 
action relating to any professional or commercial activity exercised by the diplomatic agent in the receiving State outside his official functions.

Barnett (in 2018) summarised the position under the Diplomatic Privileges Act 1964:

Under the [Act], diplomatic staff enjoy full immunity - both civil and criminal - whereas administrative and technical staff have immunity for actions taken in the course of their duties but are otherwise civilly - but not criminally liable for other acts. Members of service staff are immune only in respect of official acts. Whether a particular member of diplomatic staff falls within a certain category is determined by the Foreign Secretary by means of a certificate. The court will determine whether the action performed is within - or without - the individual's official duties. Diplomatic immunity extends to diplomatic special missions... ${ }^{65}$

In conclusion, the Diplomatic Privileges Act 1964 (see 14) should be placed in an Appendix to a BTFRA. It should include reference to diplomatic special missions, which it presently does not.

\section{CROWN PREROGATIVE - DISMISSING A FOREIGN DIPLOMAT}

Legal texts have said precious little about this. Blackstone (in 1765) remarked:

If he [i.e. an ambassador] grossly offends, or makes an ill use of his character, he may be sent home and accused before his master; who is bound either to do justice upon him, or to avow himself the accomplice of his crimes. ${ }^{66}$

Chalmers (in 1922) stated:

The sovereign can probably refuse an ambassador who is objectionable to him personally, or is otherwise objectionable. ${ }^{67}$

Keith (in 1940) stated:

Serious breach of law by a diplomat would mean, of course, an intimation to his government that his continued presence would be undesirable. ${ }^{68}$

That said, English legal texts on the constitution, generally, say nothing on the concept of an ambassador being declared persona non grata. Satow, who was not a lawyer but a diplomat, asserted in the first edition of his excellent work, A Guide to Diplomatic Practice, that:

Every state has the right of refusing to accept a particular diplomatic agent, whether on the ground of his personal character or of his previous record, as, for instance, if he is known to have entertained sentiments of enmity towards the state to which it is proposed to accredit him. A diplomatic agent may be declined because of the character with which it is proposed to accredit him, or, as it is tersely expressed in latin ex eo ob quod mittitur. ${ }^{69}$

[together with which he is being sent, i.e. due to his character]

However, today, some diplomats (especially from countries where civil and military dictatorships prevail) are of dubious reputation. Others are ex-politicians (or ex-Heads of State) where the appointment is not to the person most fitted for the post but as a political gift. To improve this unfortunate position, should not the UK set the standard? Therefore, it may be appropriate for a BTFRA to provide at any foreign ambassador (or other diplomat) cannot be accredited - or that the same will be dismissed by the FCDO - if such is 'objectionable'. For example, if such a diplomat:

(a) has committed (or commits, when a diplomat) any serious criminal offence under UK law;

(b) is a member (or becomes such) of any proscribed criminal or terrorist organisation;

(c) has been convicted (or is convicted) by any court of law in any designated country ${ }^{70}$ of:
(i) drug trafficking:
(ii) terrorism;
(iii) people trafficking;
(iv) prostitution;
(v) money laundering;
(vi) slave trading;

\footnotetext{
${ }^{65}$ Barnett, $\mathrm{n} 27, \mathrm{p} 112$. In the case of the latter, Barnett cited $R$ (Freedom and Justice Party) $v$ [SS] for Foreign and Commonwealth Affairs [ 2018] EWCA Civ 1719

${ }^{66}$ Blackstone, n 31, vol 1, p 246.

${ }^{67}$ Chalmers, $\mathrm{n} 15, \mathrm{p} 109$. He continued 'The right to receive ambassadors is more important than it at first sight appears, as no ambassador or any member of his train or any member of his family is liable to civil process, and he is probably not liable to criminal process, though Oliver Cromwell [1599-1658] is reported to have sanctioned the execution of an ambassador found guilty of murder. But modern practice is in favour of the complete extraterritoriality of diplomatic agents.'

${ }^{68}$ Keith, n 26 (this article), vol 2, p 131.

${ }^{69}$ Satow, $\mathrm{n} 4$ (this article), p 188. He provided various examples including that of Sir Stratford Canning [1786-1880] whom Tsar Nicholas refused to receive as the British ambassador to Moscow. Ibid, pp 89-92.

${ }^{70}$ It would seem apposite to include countries such as those of the EU, the US. NSTO and Commonwealth countries.
} 
(vii) genocide;

(viii) other serious crime.

(d) is (or becomes) a family member of any person on a UK (or EU or US) sanctions list;

(e) is (or becomes) a family member of any country designated as being governed by a civil or military dictatorship.

(f) is a former Head of State or President or Vice-President of any foreign country. ${ }^{71}$

The purpose of this is to weed out criminals, terrorists and persons who are on sanctions lists in order to prevent them securing diplomatic immunity to avoid great crimes - as well as avoiding the risk of them committing crimes in the UK. This would, manifestly, be in the public interest of the UK and other states with which the UK has friendly relations.

\section{In conclusion, any Crown prerogative in respect of the dismissal of ambassadors and other diplomatic officers should be abolished. The power to effect such should lie with the FCDO. And, a BTFRA should specify grounds for non-appointment (or dismissal).}

\section{CROWN PREROGATIVE - ACQUISITION \& CESSION OF TERRITORY}

Foreign territory was recognised to be acquired, under English law, by virtue of: (a) conquest; (b) cession (treaty); (c) annexation and (d) settlement. As to the meaning of the words annexation and cession, Walker indicated:

In international law, [annexation] is the unilateral act of one state in adding to its territory other territory hitherto independent, unclaimed, under protectorate or belonging to another state... ${ }^{72}$

In international law [cession is] the transfer of sovereignty over a tract of territory by one state to another. It is effected by treaty and the cause of ceding may be exchange, gift, sale, lease, pledge, merger of the ceding state with the other, or surrender after defeat in war. The treaty of cession must be completed by actual transfer to and the taking of physical possession by the other state. ${ }^{73}$

(a) Historical Position

Blackstone (in 1765-9) and Chitty (writing in 1820) did not deal with the Crown prerogative to acquire foreign territory or to cede British territory. Halsbury, Laws of England ( $1^{\text {st }}$ edition in 1909) stated:

Foreign territory may be acquired by England through settlement by British subjects, or by conquest, with or without a formal act of annexation in either case, and also by treaty, or by articles of capitulation following upon a successful war, or by the peaceful cession of territory by treaty entered into with a foreign State. Territory so acquired becomes a British colony, and the authority of the Crown extends thereto as fully in all respects as it exists in England; and though the Crown may subsequently cede such territory to a foreign State by treaty, it may not, in general, part with its prerogatives so as to constitute another sovereign in any portion of the British dominions. ${ }^{74}$

In a footnote, however, Halsbury indicated that annexation could be effected by legislation, proclamation or the authority of a royal commission under the sign manual. ${ }^{75}$ Chalmers (in 1922) summarised the position as to the cession of British territory:

Professor Maitland is of opinion that the king may cede territory, at all events, territory acquired during war, but he is uncertain as to the extent of the power. He also considers that the king cannot without a statute [i.e. without legislation] cede land subject to the [consent of the] British Parliament. ${ }^{76} \mathrm{He}$ says that parliamentary sanction was obtained to the treaty of peace after the War of Independence. Florida was ceded to Spain without a statute, but by a treaty of peace. In the following cases the Crown alienated British territory by a treaty which was neither a treaty of peace nor a treaty to avert war: (1) case of the surrender in 1817 to the Sikhim Puttee Rajah of territory formerly belonging to Nepaul [Nepal]. (2) In 1833 a surrender to Voorunder Singh of a portion of Assam,

The Rajah undertaking to abstain from torturing his subjects. The Rajah was also under the treaty to pay a large annual tribute. ${ }^{77} \mathrm{Mr}$ Forsyth also says that since the mutiny there have been several of these acessions to Indian rulers, but remarks that Indian necessities cannot be judged by European precedents. ${ }^{78}$

Anson (in 1935) stated:

\footnotetext{
${ }^{71}$ All of $(d)-(f)$ are conducive of nepotism and political favours.

72 Walker, n 78 (annexation).

${ }^{73}$ Ibid (cession).

${ }^{74}$ Halsbury, Laws (1909), vol 6, p 422.

${ }^{75}$ Ibid, (q).

${ }^{76}$ See Maitland, n 13, p 424 (with whom one would agree). See also Keith, n 26 (this article), vol 1, pp 16, 146, 223 (Heligoland).

${ }^{77}$ Chalmers cited W Forsyth, Cases and Opinions on Constitutional Law (1869), p 185.

${ }^{78}$ Chalmers, n 15, p 308 citing Forsyth, n 77 above, p 186. See also Keith (in 1936), n 26 (this article), vol 2, pp 246-7 'Nor was there any innovation in securing the approval of Parliament for the Anglo-French Treaty of 1904 which involved a cession of territory. The issue had been decided in 1890 in the case of the Heligoland under the late Queen and could not seriously be re-opened.'
} 
The cession of territory is a matter 'in regard to which the practice of consulting Parliament has varied widely from time to time $:{ }^{79}$ but the tendency has been undoubtedly in the direction of obtaining the sanction of Parliament more regularly, and not merely by an address to the Crown, or a vote signifying approval, but making the treaty or convention conditional on the approval of Parliament and by the embodiment of the provisions relating to the cession in the schedule of a statute. ${ }^{80} \mathrm{Also}$ : It may now be regarded as settled that cession of territory should be approved by Parliament, as in the case of the cession to Italy of Jubaland in 1927, and of the transfer of certain areas to Perak by the Dindings Agreement in 1934. This is in accord with the whole trend of relations between Parliament and the ministry, and the Labour ministry of 1924 adopted the rule of submitting all treaties to Parliament before ratification, but the practice is not at present followed where the issue is within the powers of the Crown. In important questions, however, the approval of the Commons is obtained before ratification. ${ }^{81}$

Anson made some very important points as to why Parliament should be involved in the cession of any territory: (i) it, necessarily, involves the rights and duties of the inhabitants of the ceded territory - especially, their nationality; (ii) it can impose a charge on the British taxpayer; (iii) cession will, often, involve tax issues, such as duties on imported and exported goods; (iv) also, matters of criminal law such as extradition treaties. ${ }^{82}$

Keith (in 1940) stated:

It appears also in strict law that a surrender of British territory by the prerogative would deprive those British subjects who remained in the ceded area of their nationality, so that in this way the king could of his own motion destroy the allegiance of subjects. But as mentioned elsewhere, since 1890 this doctrine is not acted on, and Parliamentary intervention is now regular. ${ }^{83}$

De Smith (1998) stated:

It is very doubtful whether the Crown has a prerogative to cede any part of the [UK]. But there have been past examples of the cession of parts of [HM's] dominions beyond the seas by prerogative acts (for example, the recognition of American independence in 1783), especially in treaties of peace. If this prerogative has disappeared, it is not clear how, though in modern practice the transfer of territory and the implementation of the peace treaty are always effected by statute. ${ }^{84}$

Barnett (in 2018) stated:

In 1955, the Crown exercised its prerogative power to take possession of the island of Rockall, which subsequently was incorporated into the [UK] as part of Scotland. Once territory has been annexed, the Crown has a discretion as to the extent to which it will take over the liabilities of the former government of the state. ${ }^{85}$ The Crown, also, has the power to alter the limits of British territorial waters. ${ }^{86}$ However, while this prerogative seems firmly established, there are doubts as to the power of the Crown - without Parliamentary approval - to cede territory and thereby deprive British citizens of their nationality and other rights under [UK] law. When the Crown sought to cede Heligoland [an archipelago in the North Sea] to Germany in 1890, Parliament's approval was sought. While the law may be doubtful, there is at least a convention that Parliament's approval will be sought and granted (pp 112-3).

In present times there has been a clear tendency for legislation to effect any acquisition of foreign land (such as in the case of Rockall, see Island of Rockall Act 1972) or any cession (such as in the case of Hong Kong, see Hong Kong Act 1985).

\section{(b) Conclusion}

In the modern democracy in which we live today, there is no reason (at all, one would suggest) why the Crown prerogative should continue. Instead, legislation (an Act) should provide for any acquisition or cession of land by the UK.

In conclusion, any acquisition or cession of land by the UK should be effected by legislation and not under any Crown prerogative, which should be abolished.

\footnotetext{
${ }^{79}$ Anson, n 18, vol 2, pt 2, p 137 quoting Lord Percy, moving the second reading of the Anglo-French Convention Bill; Parliamentary Debates, $4^{\text {th }}$ series, vol 135 , p 502 .

${ }^{80}$ Ibid.

${ }^{81}$ Ibid, vol 2, pt 2, p 140. Jubaland is now part of Somalia, the Dindings part of Malaysia.

${ }^{82}$ Ibid, pp 141-2.

${ }^{83}$ Keith, n 26 (this article), pp 135-6. See also vol 1, pp 16, 146, 223. For the cession of the rights of protectorates, without sanction of Parliament, Ibid, vol 1, pp 93, 225.

${ }^{84}$ De Smith, n 23, p 148.

${ }^{85}$ Barnett, n 27, p 113 referring to West Rand Central Gold Mining Co $v$ The King (1905). The Crown prerogative to alter territorial limits will be dealt with in another article.

86 Ibid.
} 


\section{CROWN PREROGATIVE - ALIENS - DENIZATION}

\section{(a) Introduction}

From earliest times, aliens (foreigners) were treated with (perhaps, an inbuilt) suspicion in England. This is unsurprising. The original Britons were suppressed by the Romans. When the Romans departed in AD 410, the Romano-British population was almost wiped out by the incoming Saxons (who came mainly from north Germany). However, they, themselves, were greatly oppressed by the Vikings who came to England from Denmark and other nordic areas in AD 866. These were only supplanted by the death of king Cnut (Canute, 101635) and his sons in 1042 and the reign of Edward the Confessor (1042-66) which re-established an Anglo-Saxon line.$^{87}$ However, victory was short lived since William I (1066-87) conquered England in 1066, bringing with him French speaking Normans, who were originally descended from the Vikings. To the original Britons, there must have been something of a Monty Python black humour about it. They were suspicious of foreigners. And, perhaps, they had some reason to be.

\section{(b) British Subjects and Aliens}

Who was a British subject and who was an alien (a foreigner) was, also, likely, only made clear with the Norman Conquest (1066). This, by means of the pre-requisite of allegiance. After the Conquest, the sovereign subjected his subjects to his rule by a process of requiring allegiance - such, being (basically) submission to his sovereignty in return for protection (military and legal) ${ }^{88}$ However, for aliens - including foreign enemies ${ }^{89}$ - there was no allegiance and no protection..$^{90}$ Instead, their ability to enter and stay in the realm of England was governed by the licence (permission) of the sovereign. ${ }^{91}$ This was usually temporary and, in time of war, foreigners could be expelled - or otherwise subject to control over their movements - by the sovereign. Foreign merchants, however, were granted a greater latitude pursuant to Magna Carta 1215 (rep). ${ }^{92}$ The result of the process of allegiance meant there was drawn (from earliest times) a legal distinction between British subjects and aliens (foreigners), as noted by Blackstone (writing in 1765):

The first and most obvious division of the people is into aliens and natural-born subjects. Natural-born subjects are such as are born within the dominions of the Crown of England, that is, within the ligeance, or as it is generally called, the allegiance of the king; and aliens, such as are born out of it. Allegiance is the tie, or ligament, which binds the subject to the king, in return for that protection which the king affords the subject. ${ }^{93}$

Chitty (writing in 1820) wrote:

Alien friends may lawfully come into the country without any licence or protection from the Crown, though it seems that the Crown, even at common law, and by the law of nations, (and independently of the powers vested in it by the Alien Act, (55 G 3 c 54) [1815] which extends even to foreign merchants) possesses a right to order them out of the country, and prevent them from coming into it, whenever [HM] thinks proper... The Alien Act [1815] ${ }^{94}$... was passed for the purpose of vesting extraordinary powers in the king and magistracy, in order that the country might be protected against aliens; it contains various wholesome provisions for that purpose. ${ }^{95}$

(c) Disabilities Imposed on Aliens

Aliens living in England had various limitations imposed on them, as Feilden (in 1911) noted: ${ }^{96}$

\footnotetext{
${ }^{87}$ Canute was king of England, Denmark and Norway. See generally, AR Rumble, The Reign of Cnut (1999), p 7 'Cnut's accession broke the line of English kings going back through the West Saxon royal family to the hero-founder, Cerdic (d. 534). Although Edward the Confessor [1042-66] was to represent the restoration of this dynasty in 1042, the preceding Scandinavian interlude of 26 years, comprising the reigns of Cnut and his sons, Harold Harefoot and Harthacnut, showed that other families could seize power. Cnut's reign therefore prerpared the way for Haold Godwineson's accession, as a non-Cerdicing, in 1066 and for the Norman Conquest that followed.'

${ }^{88}$ As Chitty, n 11, p 12 (writing in 1820) put it 'The king is entitled, morally as well as legally, to the allegiance of his subjects, in return for the protection and security which [HM] constitutionally affords them. The maxim or rule 'Protectio trahit subjectionem, et subjectio protectionem' has obtained in every age, and in every country; and extends not only to those who are born within the king's dominions, but also to foreigners who live within them, though the sovereign is at war with this country; for they equally enjoy [HM's] protection.'

${ }^{89}$ Aliens were invariably categorised, for legal purposes, into: (a) friendly aliens; (b) enemy aliens. See, for example, Chalmers (in 1922), $\mathrm{n}$ $15, \mathrm{p} 80$.

${ }^{90}$ Phillips \& Jackson (in 2001), n 30 (this article), p 512 'Under the medieval common law aliens had practically no public or private rights', One would agree.

${ }^{91}$ Ibid, p 512 'At common law an alien probably had no right to enter the country.' This was almost certainly the case (and no different to foreign countries) since the sovereign owned the land and, in the case of England, an alien (if unlicensed) was trespassing on the same. For the sovereign's licence see also, Phillips \& Jackson, n 30, p 513.

${ }^{92}$ See Chitty, n 11, 49. See also Magna Carta 1215, c 30.

${ }^{93}$ Blackstone, n 31, p 354.

${ }^{94}$ See 55 G 3 c 54.

${ }^{95}$ Chitty, n 11, p 49.

${ }^{96}$ See also Plucknett, n 20, pp 678-81. Feilden fails to note the explusion of c. 2000 Jews from England by an edict of Edward I (1272-1307) on 18 July 1290 .
} 
Although aliens before the Norman Conquest [1066] were under the king's protection, they were for long regarded in England with peculiar jealousy e.g. in 1258, 1404, 1571 and 1575, they were expelled from the realm; they were subject to higher rates of taxation, and the 'alien tax' was often imposed, e.g.

$1439,1442,1449,1453,1483$...Aliens were frequently subjected to repressive legislation. In 1380 (3 Ric II c 3), they were forbidden to hold benefices; ${ }^{97}$ in 1414 , to hold land, or engage in retail trade; in 1484, and 1523, to have foreign apprentices; and in 1540, to take any shop or dwelling on lease. ${ }^{98}$

An alien may become a British subject by denization, e.g. by letters patent issued by virtue of the King's prerogative, or by naturalisation, e.g. by Act of Parliament, or by a certificate from the Home Secretary, on taking the oath of allegiance (in accordance with the Naturalisation Act of 1870). In 1610 (7 Jac 1, c 2), the condition of naturalisation embraced receiving the sacrament, and taking oaths of supremacy and allegiance; the necessity of taking the sacrament was abolished [in] 1825...By the Act of Settlement, 1701 [1700], owing to the jealousy with which the foreign favourites of William III [1688-1702] were regarded, it was enacted that no alien, even though naturalised or a denizen - unless born of English parents - shall be capable of sitting in Parliament, or holding any office or place of trust, or have any grant of land from the Crown. Although this enactment was sometimes relaxed by special Acts of Parliament in favour of particular individuals, it was confirmed on several occasions, e.g. 1740, 1749. In 1774, it was provided that no Bill for naturalisation should pass, unless it contained a clause deferring the immunities and indulgences of natural-born subjects until after seven years' residence.

In 1793, in consequence of the alarm existing at the influx of large numbers of French refugees, Lord Grenville's Alien Act [1793] was passed, subjecting them to most strict regulations; ${ }^{99}$ it was subsequently re-enacted as occasion demanded until 1826. [a fn adds An Alien Bill was passed in 1905 (5 Ed VII c 13) to exclude diseased and criminal aliens, and to expel undesirable aliens]. In 1827, and 1836, measures were adopted for the registration of aliens; in 1844, Mr Hutt's Act increased the facilities for naturalisation, and extended the consequent privileges. ${ }^{100}$ By the Naturalisation Act of 1870 (33 \& 34 Vict c 14 ss 2,7) an alien may acquire, hold, and dispose of real and personal property, with the exception of British ships, like a natural-born subject, and has all the rights and privileges of a British born subject, except the franchise, and the power of holding municipal or parliamentary office. An alien, by obtaining a certificate of naturalisation from the Secretary of State, acquires all political as well as all civil rights. 101

Until 1870, the greatest limitation generally on an alien was that, under the common law, such could not hold real property in England. ${ }^{102}$ Therefore, given these limitations, for an alien who wanted to live in England for any extended period of time, that there was real impetus to seek either:

- Naturalisation; or

- Denization.

An alien could become a British subject by naturalisation (which could be effected only by Act of Parliament). However, there was a half-way house, denization. There was a considerable difference between the two, since the obligations imposed for naturalisation were, sometimes, unacceptable to aliens on religious grounds. Plucknett stated:

An alien might become, to a certain extent, an English subject either by denization under the king's letters patent, or by naturalisation by a personal act of Parliament, the latter mode not merely enabling him to hold land, but to inherit it from others and to transmit it by inheritance to his children, whether born before or after his naturalisation. By statute 7 Jac 1 c 2 (1610), it was, however, enacted that no person should be naturalised unless he should first take the oaths of allegiance and supremacy in the presence of the parliament and also take the sacrament. ${ }^{103}$

\footnotetext{
${ }^{97}$ See also Blackstone, n 31, vol 4, p 111. Also, vol 2, pp 249-50 (descent etc), 274 \& 293.

${ }^{98}$ See also Chalmers $\left(5^{\text {th }}\right.$ ed, 1936), n 15, p 321 who noted 'At common law they could be expelled at the royal pleasure, this prerogative right being last exercised in 1575.' Chalmers observed (in a fn) 'It is quite easy to expel aliens from the realm today, under the Alien Immigration Acts, for any or no specified reason.'

${ }^{99}$ Ibid, p 322 'During the wars with France in the eighteenth and nineteenth centuries aliens were placed from a time under severe restrictions, but these gradually disappeared after Waterloo [in 1815].'

${ }^{100}$ Ibid, 'In 1844 aliens obtained certain advantages under Hutt's Act, which enabled them (inter alia) to be naturalised under a certificate of the Home Secretary on taking an oath of allegiance, but they could not become members of Parliament or of the privy council, neither could they enjoy rights excepted by the certificate.' Maitland, n 13, p 384 'In 1844 a general statute was passed giving power to the Home Secretary to grant certificates of naturalization: thus recourse to parliament was rendered unnecessary.'

${ }^{101}$ Feilden, n 14, pp 236-7.

${ }^{102}$ Maitland, n 13, p 426 'By the common law, and down to 1870, an alien could not hold real property in England...In 1870 the law was changed by the Naturalization Act (33 and 34 Vict, c 14) which declared that real and personal property of every kind in the [UK] might be acquired, held, and disposed of by an alien, as though he were a British subject; but he was not qualified to be the owner of a British ship; and the act did not qualify him for any office, or for any franchise, or for any parliamentary, municipal or other franchise.'

${ }^{103}$ Plucknett, n 20, p 679
} 
The requirement of taking the sacrament was not to be abolished in all cases until $1825 .{ }^{104}$ The remainder of this section concerns only denization (for naturalization see 10).

\section{(d) Denization of Aliens}

Denization occurred under the Crown prerogative but was not the same as naturalisation. Blackstone (writing in 1765) stated:

A denizen is an alien born, but who has obtained ex donatione regis ${ }^{105}$ [by gift of the sovereign] letters patent to make him an English subject : a high and incommunicable branch of the royal prerogative [i.e. one which could not be franchised]. A denizen is in a kind of middle state between an alien, and [a] natural born subject, and partakes of both of them. He may take lands by purchase or devise, which an alien may not; but cannot take by inheritance: for his parent, through whom he must claim, being an alien had no inheritable blood, and therefore could convey none to the son. And, upon a like defect of hereditary blood, the issue of a denizen, born before denization, cannot inherit to [meaning 'from'] him; but his issue born after, may. A denizen is not excluded from paying the alien's duty, and some other mercantile burthens. And no denizen can be of the privy council, or either house of parliament, or have any office of trust, civil or military, or be capable of any grant from the Crown. ${ }^{106}$

As to denizens, Chitty (writing in 1820) noted:

$[\mathrm{HM}]$ is, however, is however, entrusted with an important power of making an alien a denizen; which is a kind of middle state between an alien and natural born subject, and partakes of them of both of them. Denization enables an alien to purchase, and to transmit lands by descent etc but does not qualify him to take any degree of nobility or to sit in Parliament, be of the privy council, or to hold any office of trust, civil or military, or take any grant of lands from the Crown. This prerogative cannot be delegated by the Crown to any one, and should be granted according to the statute 32 Hen 8 c 16 s 7 [1540] with a proviso in the letters patent, that the denizen shall be obedient to the statutes in force before the making of that statute: but such proviso does not constitute a condition; and therefore the denization is not avoided by the denizen being guilty of a breach of the laws. Denization may be granted for life, or for years; or to the alien born, and the heirs of his body, or to the heirs generally; or for particular purposes and intents, and in certain places, and no further, or upon condition. ${ }^{107}$

\section{(e) Naturalisation Act 1870}

Seeking denization became increasingly rare due to the increasing removal of disabilities imposed on aliens seeking naturalisation. Also, because the Crown prerogative to denizize a person could not make the same capable of inheriting. The Naturalisation Act of 1870 (greatly) simplified matters in respect of naturalisation, such as to make denization obsolete. Maitland (writing in 1887-8) explained:

An act of Parliament might of course turn an alien into a subject, and until lately acts having the object of naturalising this or that foreigner were not uncommon. A statute, however, was unnecessary; it seems to have been established at an early time, certainly before Coke, that the king without Parliament could not turn an alien into a subject for all purposes. He might for some, but not for all.

This doctrine gave rise to the class of persons known as denizens - intermediate between subjects and aliens. The denizen was so made by the king's letters patent, i.e. by an act done by the king without Parliament. The limit to the royal power (as I understand it) was this: the person whom the king made a denizen of his realm became capable of acquiring lands by purchase or devise, and of holding them when acquired, and in general he became a subject of the realm, but the king could not make him capable of inheriting. An Act of Parliament might of course do even this, and Naturalization Acts (I believe) usually did it, but the king could not do it....

The Act of 1870, amending the previous Act of 1844, has provided a mode whereby persons may be naturalised without special Act of Parliament, but has expressly preserved the queen's power of granting letters of denization. I should imagine that such power is seldom if ever used, for it is easy to become naturalised. British nationality can now be granted by a Secretary of State. The applicant must have resided in the [UK] for five years, or have been in the service of the Crown for five years, and must intend when naturalised to reside in the [UK], or to serve under the Crown. The Secretary has the absolute discretion in giving or withholding the desired certificate, and need assign no reason for refusal. The oath of allegiance must be taken. If the certificate be granted, then the naturalised alien shall, within the [UK], have all political and other rights and privileges to which a British subject is entitled. ${ }^{108}$ (italics supplied)

In short, over a hundred years ago, denization under the Crown prerogative began to become obsolete. Thus, Anson (writing in 1935) stated:

\footnotetext{
${ }^{104}$ Ibid. See also 10

${ }^{105}$ It was for this reason that the law dictionary, Termes de la Ley (last ed, 1721, rep Law Book Exchange) (denizen), thought the true word was donaison. This prerogative could not be franchised, as the Termes noted. See also 1st English edition of the same published in 1579. The practice of issuing letters of denizen was pre-1340 since an Act of that year (14 Edw 3 st 2 c 2, s 1) refers to denizens.

${ }^{106}$ Blackstone, n 31, vol 1, p 362.

${ }^{107}$ Chitty, n 11, pp 14-5. Also, Bowyer, n 12, p 406.

${ }^{108}$ Maitland, n 13, p 428. Also, Amos, n 73, pp 184-5.
} 
The Crown can confer a quasi-naturalisation by letters patent. The person so privileged is called a denizen...He is, since 1870 , in no better position practically, than an alien, and the practice though still possible is probably obsolete. ${ }^{109}$

\section{(f) Denization Obsolete}

Today, denization is obsolete, with it being supplanted by naturalisation. And, naturalisation is effected pursuant to legislation. Thus, any Crown prerogative to make a person a denizen should be abolished. Wording in the Act of Settlement 1700, s 3 referring to a 'denizen' should be repealed.

\section{In conclusion, any Crown prerogative to make a person a denizen should be abolished. 10. CROWN PREROGATIVE - ALIENS - NATURALISATION}

\section{(a) Naturalisation of Aliens}

There is no Crown prerogative to naturalise aliens. Thus, Blackstone (in 1765) stated:

Naturalization cannot be performed but by Act of Parliament: for by this an alien is put in exactly the same state as if he had been born in the king's ligeance; except only that he is incapable, as well as a denizen, of being a member of the privy council, or Parliament etc. ${ }^{110}$

Chitty (in 1820) stated:

By various Acts of Parliament [now repealed], persons not natural born subjects may, in certain cases, become naturalised, as if they were born within the king's territories... Though it has been asserted that the king may nullify for the future, that allegiance which natural born subjects owe him, by ceding a colony in which they live to another potentate; yet there can be no doubt that [HM] is not by law enabled to naturalise an alien. To effect that, an Act of Parliament is necessary, and such acts cancels all defects of blood, and has a retrospective energy, so as to enable a son born before the naturalisation, to inherit etc; an effect and power which do not attach to simple denization. ${ }^{111}$ (italics supplied)

As previously noted (see 9(c)), the Naturalisation Act 1870 removed many disabilities. ${ }^{112}$ This Act also impliedly repealed the Act of Settlement 1700, s 3 which provided that no person born outside the UK or the dominions thereunto belonging (although he be made a denizen) except he be born of British parents, could be a privy councillor or a member of either House of Parliament or of holding any office or place of trust, either civil or military. ${ }^{113}$

\section{(b) Disabilities in 1936}

As it is, by 1936 (when Chalmers wrote) a naturalised alien was free from all incapacities (i.e. the same as a British subject) save in respect of two, (a) parliamentary and municipal franchise; (b) owning a British ship. He stated:

So long as the State to which he belongs is at peace with [HM], an alien in England enjoys full civil, as opposed to civic or political, rights. He owes 'temporary allegiance', and as he is subject to our laws, he enjoys their protection, e.g. he can bring and defend actions and institute prosecutions. He can acquire land, has full personal liberty, and can generally do as he pleases; but though he must pay taxes when domiciled in England, he cannot exercise either the parliamentary or municipal franchise; neither can he own a British ship or any share therein. In $R v$ Arnaud (1846), 19 QBD 806, it was held that a company which had been registered in this country could own a British ship although all its members were aliens. ${ }^{114}$

As to any restriction on an alien being a member of the privy council, this was contraverted in Speyer's Case (1916) as summarised by Chalmers:

In Speyer's Case ( $R$ v Speyer, [1916] 2 KB 858, CA) it was held that a naturalised alien could be a member of the Privy Council. Proceedings in the nature of a writ of quo warranto were instituted to determine the legality of Sir Edgar Speyer's appointment as a privy councillor, and the statutes relevant to the claim were as follows: The Act of Settlement ([s] 3) provided that nobody born abroad or outside the British Dominions, though 'naturalised or' a denizen, except born of English parents, should be eligible for (inter alia) the Privy Council. By [s] 7 of the Naturalization Act, 1870, persons duly naturalised thereunder were to be entitled to all political and other rights of a British subject. By [s] 3 of the British Nationality and Status of Aliens Act, 1914, holders of a certificate of naturalization in the UK were to have all political and other rights attaching to a natural-born British subject, and it

\footnotetext{
${ }^{109}$ Anson, n 18, vol 2, pt 1, p 288. See generally, his ch 6. See also Chalmers (in 1922), n 15, p 83 'Letters of denization are hardly ever now granted'. Repeated in $5^{\text {th }}$ ed in 1936, p 385. Walker (in 1980), n 78 (denizen) 'The grant is in the discretion of of the sovereign and is now almost obsolete, being replaced by naturalisation'.

${ }^{110}$ Blackstone, n 31, vol 1, p 362.

${ }^{111}$ Chitty, n 11, pp 14-5.

112 This Act of 1870 was repealed by the British Nationality and Status of Aliens Act 1914. By 1960, this had become the British Nationality and Status of Aliens Acts 1914 to 1943 . These were repealed by the British Nationality Act 1981.

${ }^{113}$ Act of Settlement 1700, s 3. However, this was only impliedly. Thus, the matter is not wholly beyond doubt. Cf. being an MP, see McBain, $\mathrm{n}$ 1, (Parliament), p 150-1. See also Halsbury, Laws, vol 6 (1909), para 565, n (p) for the argument as to implied repeal.

${ }^{114}$ Chalmers, n 15, p 323. For the position by 1960, see Plucknett, n 20, p 681.
} 
was further provided that [s] 3 of the Act of Settlement, as regarded 'naturalised or' were omitted therefrom. The court held that the Act of 1870 had repealed by implication [s] 3 of the Act of Settlement as regards naturalized subjects, and that as the Act of 1914 had not revived the disqualification the appointment of Sir Edgar Speyer was valid. ${ }^{115}$

\section{(c) $\underline{\text { Conclusion }}$}

The Crown has never had a prerogative to naturalise a person. This has always been statutory ${ }^{116}$ and, if required to provide certainty, this should be stated in a BTFRA. Any limitation on a naturalised person being a: (a) privy councillor; ${ }^{117}$ or (b) MP; or (c) holding any office or place of trust - civil or military, should be abolished. ${ }^{118}$ Perhaps, with some other limitations imposed. ${ }^{119}$ As to the right of aliens to enter the realm - and to stay in realm - this will be considered in an article on the Armed Forces since such, often, occurred in the context of the war.

\section{In conclusion, a BTFRA should stipulate (if thought necessary) that the Crown has no power to naturalise a} foreigner.

\section{CROWN PREROGATIVE - PASSPORTS}

\section{(a) Introduction}

Prior sections of this article have discussed aliens in the context of the Crown prerogative to make them denizens (which was possible) or to naturalise them (which was not possible, legislation was required). What is now considered is how aliens came into the realm of England in the first place.

\section{(b) Letters of Safe Conduct}

The legal position, certainly after the Norman Conquest (1066) seems to have been very clear. Because, William I (1066-87) claimed title to all England - as the landowner of the same - he could dictate who came and who stayed. Also, by establishing a system of feudal tenure (i.e. English land held from the sovereign on the condition of performing military (or other) service obligations, together with an acknowledgement of allegiance to him), there was made a clear-cut divide between:

\section{- $\quad$ British subjects; and \\ - $\quad$ Aliens (foreigners).}

The first owed allegiance; the second did not. If the first breached that allegiance by making war on the sovereign, it was high treason. If the second, they became the enemy. Both could be killed in battle under the law martial and it was not murder (it also seems clear that the courts were not interested in becoming involved in the legality of such things). ${ }^{120}$

- $\quad$ British Subject. For the British subject, they had a right to live (reside) in England under the sway of their (new) Norman rulers. At the time of the Norman Conquest (1066), they would have comprised former British stock, AngloSaxons, Danes and Vikings. In due course, they became 'English' and, with the extension of the Crown, in due course, Ireland, Wales and Scotland were added, so they became British. However, subjects could be expelled. The only way for this to happen was for a person to be declared an 'outlaw'. If such, as in Anglo-Saxon times, that person was treated as having the 'wolf's head' on them. If they did not hand themselves into justice, they could be killed on sight and it was not murder. However, if they managed to flee to a church and seek sanctuary, they could not be killed on sight. Instead, they had to leave the realm forthwith. The route (they had to use the king's highway) and the port by which they must leave (often, it was Dover) were designated and - if they strayed from that route - they could (lawfully) be killed. It was not murder. ${ }^{121}$

- $\quad$ Aliens. However, for the alien, the position was completely different. And, very simple in simple times. They could only enter the realm with the permission of the landowner (the sovereign). Otherwise, it was trespass. Further, they ran a real risk. If in war time, they could be treated as enemies and killed (if they opposed seizure). ${ }^{122}$ Also, as with British subjects, they (generally) had to keep to the king's highway. If they strayed from it, they could be mistaken for thieves (if they did not ring a bell or make other sound). As such, if they had any stolen goods on them, they

\footnotetext{
${ }^{115}$ Ibid, p 322. Edgar Speyer (1862-1932) was an American born financier and philanthropist, made privy councillor in 1909.

${ }^{116}$ By 2001, it was governed by the British Nationality Act 1981, s 6 \& sch 1, see Phillips \& Jackson, n 30 (this article), p 508.

${ }^{117}$ A previous article has proposed that the privy council be abolished, see McBain, n 1 (Government Act), pp 82-4.

${ }^{118}$ For the position by 2001, see Phillips and Jackson, n 30 (this article), p 513. This has further changed.

${ }^{119}$ If one abolishes the Settlement Act 1700, s 3 then it would mean that, for example, the passport holder and citizen (say, a spy) of a hostile country to the UK could become a naturalised person in the UK and, then, seek to attain the highest military office or become an MP. In the present state of affairs, great caution (it is suggested) should be exercised, especially where people hold one or more other passports.

${ }^{120}$ See GS McBain, Abolishing Obsolete Crown Prerogatives relating to Martial Law, Conscription and Billeting [2012] International Law Research, vol 1, no 1, 13-52.

${ }^{121}$ See GS McBain, Modernising the Law: Breaches of the Peace and Justices of the Peace (2015) Journal of Politics and Law, vol 8, no 3, $\mathrm{p}$ 175. Doubtless, many a time, victims of such outlaws 'helped' them stray from the king's highway by force and, then, killed them.

${ }^{122}$ Coke asserted that a subject might lawfully dispossess an enemy alien in war time. Coke, $\mathrm{n} 29$, vol 4, p 154 'for if he which took them was in enmity with the sovereign of him whose goods were taken, then it was no depredation or robbery, but a lawful taking, as every enemy might take of another'. Ibid, p 141. Blackstone (in 1765), n 31, vol 2, p 401 was in dis-agreement.
} 
could be killed and it was not murder. Doubtless, however, many an honest foreign merchant in early medieval times carrying his wares was deliberately 'mistaken' for a thief by locals and robbed (and killed).

Did many aliens come to England in the period from the Norman Conquest (1066) up to the reign of Henry II (1154-89)? One is dubious. The realm was, often, lawless especially in the north and west of England - and especially during the early years of the reign of William I (1066-87) and during the Civil War (1135-54). Those aliens who did come would have been:

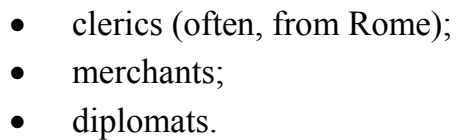

These would have headed for the major towns, mainly London. In the case of these, merchants had no right to own property and they could only stay for 40 days at most (save for the German merchants of the Steelyard or where a treaty otherwise provided). ${ }^{123}$ No aliens would have come to England during winter anyway (the sea crossing was too dangerous, which is why war with England was only conducted during the spring and the summer). Aliens would have had to have a letter of safe conduct to enter the realm. ${ }^{124}$ And, given that the UK is an island, entry would only have been via a seaport. For foreigners that port was (almost invariably) Dover since it was the only one with a decent road and with Crown messenger posts (which meant inns as well where they could stay). ${ }^{125}$ When were letters of safe conduct to aliens first granted by the Crown? At least, from the time of king John (1199-1216) and, one suspects, considerably before.

In conclusion, from early times, aliens could only enter England if they had the sovereign's licence in the form of a letter of safe conduct. They could only stay for a limited period of time. And, they could only enter England via a designated seaport. In war time they could be expelled forthwith.

\section{(c) From 1215-Victorian times}

The system of letters of safe conduct survived for centuries. It was a simple and effect means of controlling the entry of foreigners into England. Further, aliens lived a precarious existence. They could not, as noted, own property. Further, they could be expelled simply by the sovereign withdrawing his licence, as Edward I (12721307) did with the Jewish people in 1258 and Elizabeth I (1558-1603) did with the German merchants of the Steelyard in London in 1597.

- It seems likely that the word 'passport' came into use as an alternative (French derived) expression for the words 'letter of safe conduct' since the word seems to have been first used in 1548 legislation of Edward VI (1547-53); ${ }^{126}$

- It may also have been that the 'letter of safe conduct' referred to that granted by the Chancery 127 and 'passport' referred to a letter of entry or certificate granted by the British ambassador aboard. ${ }^{128}$ For example, Blackstone (in $1765)$ referred to 'safe-conducts' or 'passports' expressly granted by the king or his ambassadors '.'29

It may also have been that, in times of extended peace, the legal requirement that an alien must have a letter of safe conduct was relaxed, in order to encourage trade. ${ }^{130}$ Thus, Blackstone (in 1765) also noted:

Upon exactly the same reason [of reciprocity] stands the prerogative of granting safe-conducts, without which by the law of nations no member of one society has the right to intrude into another. And therefore Puffendorf ${ }^{131}$ very justly resolves, that it is left in the power of all states, to take such measures about the admission of strangers as they think convenient; those being ever excepted who are driven on the coasts by necessity, or by any cause that deserves

\footnotetext{
${ }^{123}$ See GS McBain, The Strange Death of the Law Merchant [2016] International Law Research, vol 5, no 1, p 42. The Germans were subjects of the German emperor and they had a trading post at the 'Steelyard' (from the lower german, stalhof) on the banks of the Thames (now Canon Street) from AD 900-1597. Henry III (1216-72) granted a charter to them. Elizabeth I (1558-1603) ordered the expulsion of the Hanseatic League in 1597 and the closure of their premises.

${ }^{124}$ See generally, McBain, n 120 (this article), pp 23-6.

${ }^{125}$ Since aliens could not own real property they had to stay in hostels (inns) and their host was responsible for them. See GS McBain, Abolishing the Strict Liability of Hotelkeepers [2006] JBL, October, p 709 and The Statute of Winchester (1285) 'no man do lodge in suburbs, nor in any place out of town, from nine of the clock until day, without his host shall answer for him.'

${ }^{126}$ See the law dictionary, Termes de la Ley (last ed, 1721, rep Law Book Exchange), n 105 (this article) (passport), 'Passport is a word mentioned in the statute of 2 E[dward] 6 c 2 [1548] and signifies a licence made by any that has authority for the safe passage of any man from one place to another.' Section 10 of this Act of 1548. It stated 'no captain....shall give to any of his soldiers, appointed to serve under him in any town or fortress kept with garrisons of soldiers, any licence or passports to depart from his service...'. (italics supplied)

${ }^{127}$ Calvin's Case (1608) 7 Co 1a, at 25b (77 ER 377) 'The king only....may make...letters of safe conduct.'

${ }^{128}$ Passports have been called 'letters' and 'certificates'. e.g. Walker, n 78, (passport) 'A certificate issued by the Foreign Office to citizens of the [UK] and colonies, British subjects without citizenship and British protected persons, certifying their identity and citizenship and requesting British consuls and officials abroad to give them protection and any necessary assistance when travelling abroad.'

${ }^{129}$ Blackstone, n 31, vol 4, p 68. See, also, the categorisation of Emer de Vattel (1714-67), a Swiss jurist, see McBain, n 120 (this article), p 25

${ }^{130}$ By Coke's time it seems that only aliens of countries at war with England needed a letter of safe conduct to enter the realm, see GS McBain, Abolishing Obsolete Crown Prerogatives relating to the Military (2011) Nottingham LJ, vol 20, p 24. Soo too, foreign sovereigns.

${ }^{131}$ Samuel von Pufendorf (1632-94), a German jurist, in his work, Law of Nature and Nations (1672) (De Iure Naturae et Gentium).
} 
pity or compassion. Great tenderness is shown by our laws, not only to foreigners in distress (as will appear when we come to speak of shipwrecks) but with regard also to the admission of strangers who come spontaneously. For so long as their nation continues at peace with ours, and they themselves behave peaceably, they are under the king's protection; though liable to be sent home whenever the king sees occasion. (italics supplied). ${ }^{132}$

The wording in italics expresses the nub of the matter. The sovereign as lord paramount of the land (the realm of England) could determine, at will, who was a trespasser or not. Chitty (writing in 1820), ${ }^{133}$ stated:

$[\mathrm{HM}]$ may...permit an enemy to come into the country without molestation, by granting to him letters of safe conduct.

These letters ought to be under the great seal, and inrolled in Chancery. But passports under the king's sign manual or licences from his ambassadors abroad are now more usually obtained, and allowed to be of equal validity. ${ }^{134}$

For British subjects, there was no licensing system. They could leave and enter the UK without a passport. ${ }^{135}$ Doubtless, because of the problems which his engendered (especially, where British subjects had a foreign spouse), from 1793, there was greater statutory regulation of aliens. Thus, by legislation, from 1793, aliens were required to obtain from the mayor, chief magistrate or justice of the peace of the county etc a 'passport' containing their name and description. ${ }^{136}$ As for British subjects, between 1836-1914, it seems that there was no legal requirement for a British subject to have a passport, although a visa system operated between Britain and some European countries. ${ }^{137} \mathrm{Up}$ to the $20^{\text {th }}$ century there was little law on passports with, for example, Halsbury, Laws of England ( $1^{\text {st }}$ edition in 1909) simply stating:

Passports may be granted by the Crown at any time, to enable British subjects to travel with safety in foreign countries, but such passports would clearly not be available so as to permit travel in the enemy's country during war. Passports are issued by the Foreign Office or by diplomatic officers abroad... ${ }^{138}$

The right to issue, refuse, impound and revoke (i.e. withdraw) a passport is that of the Crown. However, especially in modern times - and with regard to the development of human rights - it is important that the law in this area is clear.

\section{(d) Evolution of Law on Passports}

De Smith (writing in 1998) noted:

[UK] passports are issued under the royal prerogative by the passport agency (an executive agency within the $[\mathrm{HO}])$. They may be refused, revoked and impounded in the absolute discretion of the Crown, and there is no formal machinery for appeal, but a person aggrieved can obtain judicial review of a decision adverse to his interests. In form a passport is a request in the Queen's name to afford the holder free passage and any necessary assistance; it is also a certificate of identity and citizenship. A holder (provided, at least, that he is in fact a citizen) is entitled to the diplomatic protection of the [UK] government in a foreign country, though any such duty cast upon the Crown does not appear to be directly enforceable in judicial proceedings...In practice it is extremely difficult to travel outside the country without a valid passport or national identity card, because carriers will demand production of passports by passengers, and immigration authorities elsewhere will not normally accept the entry of non-passport holders. ${ }^{139}$

Phillips and Jackson (in 2001) stated:

The [SS] has a discretion to grant, refuse, impound or revoke passports, which remain Crown property. A passport was defined by Lord Alverstone $C J$ in $R v$ Brailsford ${ }^{140}$ as ' $a$ document issued in the name of the sovereign on the responsibility of a minister of the Crown to a named individual, intended to be presented to the governments of foreign nations and to be used for that individual's protection as a British subject in foreign countries.' It contains a request in the name of [HM] to allow the bearer to pass freely, and to afford him such assistance and protection as

\footnotetext{
${ }^{132}$ Blackstone, n 31, vol 1, p 251-2. He continued 'But no subject of a nation at war with us can, by the law of nations, come into the realm, nor can travel himself upon the high seas, or send his goods and merchandize from one place to another, without danger of being seized by our subjects, unless he has letters of safe conduct; which by divers ancient statutes must be granted under the king's great seal and inrolled in chancery, or else are of no effect: the king being supposed the best judge of such emergencies, as may deserve exception from the general terms of the law.'

${ }^{133}$ Chitty, n 11, pp 48-9.

${ }^{134}$ He referred to Blackstone, n 31, vol 1, p 260 (actually p 259) and vol 4, p 68

${ }^{135}$ The only exceptions under the common law lay in the prerogative of the Crown to prevent a British subject from leaving the realm or ordering him to return to the realm. However, these had become obsolete by the time of Blackstone. In any case, they had been exercised for political or military reasons. See McBain, n 120 (this article), pp 26-35.

${ }^{136}$ Ibid, McBain, p 25. Ibid, p 6 'With respect to foreign states and affairs, the whole majesty and power of his dominions are placed in the hands of the king, who as representative of his subjects possesses discretionary and unlimited powers. In this capacity [HM] has the sole right to send ambassadors and other foreign ministers and officers abroad, to dictate their instructions, and prescribe rules of conduct and negotiation. $[\mathrm{HM}]$ alone can legally make treaties, leagues and alliances with foreign states...'.

137 Ibid.

${ }^{138}$ Halsbury, Laws (1909), vol 6, p 439.

${ }^{139}$ De Smith, n 23, pp 422-3.

${ }^{140}$ [1905] 2 KB 730, 745
} 
may be necessary. The Crown has a duty to protect its citizens abroad, although this is not legally enforceable. A passport is not legally necessary at common law in order to go abroad, but it is universally used as a certificate of identity and nationality. Other countries may refuse entry without possession of one, and therefore transport companies may be expected to refuse to carry passengers abroad without passports. The alleged prerogative power of the Crown to refuse or impound passports has been described as arbitrary, objectionable and of doubtful validity. Further, the right of establishment in community law means that nationals are entitled to identity cards or passports enabling them to leave and re-enter the country freely, subject to public policy, security and health. ${ }^{141}$

Bradley (in 2018) stated:

The issue of passports to citizens is based on the prerogative, as are the conditions under which such passports are held, though there are now also statutory powers authorising ministers to require passports to be surrendered. ${ }^{142}$

He referred to the Counter-Terrorism and Security Act 2015, s 1 which provides:

(Seizure of passports etc from persons suspected of involvement in terrorism). (1) Schedule 1 makes provision for the seizure and temporary retention of travel documents where a person is suspected of intending to leave Great Britain or the $[\mathrm{UK}]$ in connection with terrorism-related activity.

Barnett (2020) stated:

Consistent with the Crown's power to regulate its boundaries and those who enter and leave is the power to issue passports: again, under Blackstone's definition, this is a questionable prerogative power, for the government is doing no more than what it is free to do under statute and the power has no legal effect as such. ${ }^{143}$

There is merit in this. However, the legal history needs to be considered. Any person has a right to prevent trespass on their land. And, in 1066, William declared that all England belonged to him (as lord paramount).

Thus, as landowner, he was entitled to control access to the same. This is still the position. As it was, access to the realm was only permitted when the sovereign certified such. In the case of British subjects this was implicit as a result of their presence and landholding. In the case of foreigners (aliens) this was only permitted when, from an early time, the sovereign issued a formal document - a letter of safe conduct. The passport was the successor to that. And, it was first issued to foreigners, not to British subjects. Today, it is issued to British subjects as well, mainly for their convenience to travel abroad. Thus, the Crown prerogative exists. However, the sovereign is no longer involved in such and legislation, it is asserted, should, now, wholly govern the matter.

Barnett also states:

At common law, [British] citizens have the right to enter and leave the realm. It is nevertheless extremely difficult

in practice to travel without a passport, which is issued under the prerogative. In $R v$ Foreign Secretary ex parte Everett (1989), the court for the first time held that the granting and withholding of passports was subject to review by the courts...In $R(X H) v$ [SS] for the Home Department (2017) the Court of Appeal held that the executive retained the prerogative power to refuse to issue or to cancel a passport issued to a person whom the Home Secretary was satisfied had been involved in terrorist activities. The clamant had argued that the purported exercise of the prerogative was invalid because that power had been impliedly abrogated by the Terrorism Prevention and Investigation Measures Act 2011. The court disagreed - there being no express restriction in the Act, to succeed the claimant had to show that the prerogative was abridged or abrogated by 'necessary implication'. Necessary implication is a strict test and this case was not established. ${ }^{144}$

\section{(e) $\underline{\text { Conclusion }}$}

As indicated in an article, letters of safe conduct have been superceded by the passport (by Victorian times) and any Crown prerogative to issue the former should be abolished. ${ }^{145}$ Further, it is asserted that any Crown prerogative to issue a passport should be abolished as well. Instead, provision should be made in legislation that the relevant government department (the Passport Agency) is authorised to issue a passport to a 'qualified person.' That is, to a UK citizen (including a naturalised person). Further, the grounds on which a passport may be:

- $\quad$ Refused to be issued;

- Revoked (i.e. withdrawn, cancelled) or,

- Impounded (seized).

should also be set out in legislation. This would not only clarify matters. It would make the issue, refusal to issue, revocation and impounding a justiciable issue. This seems appropriate where the sovereign in person is no longer involved in such matters and where a British citizen should have a democratic right to have a passport (in order

\footnotetext{
${ }^{141}$ Phillips \& Jakson, $\mathrm{n} 30$ (this article), p 326.

${ }^{142}$ Bradley, $\mathrm{n} 26$, p 261. For a discussion of terrorism and legislative measures. Ibid, pp 555-75 especially pp 571-2 re passports.

${ }^{143}$ Barnett, n 27, p 106.

${ }^{144}$ Ibid.

${ }^{145}$ See McBain, $\mathrm{n} 1$ (Crown Act), pp 24 \& 46.
} 
to go abroad). ${ }^{146}$ However, since there are also (likely) to be very many false UK passports floating around (and many frauds to get a passport), legislation should also provide that, any time, the Passport Office may require a person to submit proof that they are validly entitled to the passport which they are purporting to use.

\section{CROWN PREROGATIVE - DIVESTMENT OF BRITISH (UK) NATIONALITY}

\section{(a) Background - Renunciation of Nationality by British Subject}

In the past, a British subject would rarely have sought to divest him (or her) self of nationality, given that it was to be preferred to that of most other countries. Indeed, it seems that, at common law, no British subject could, voluntarily, become an alien. Thus, Chalmers (in 1922) stated:

At common law no alien could by any voluntary act become a British subject, nor could any British subject become an alien (nemo potest exuere patriam)...A British subject could not at common law, but may now, become naturalised in a foreign country, and any person so doing ceases to be a British subject. ${ }^{147}$

The above refers to voluntary alienage by a British subject as a result of legislation. Thus, Ridges (edited by Keith in 1934), referring to 'Loss of British nationality', stated:

A person born within the king's dominions or allegiance, or on a British ship, if at the time of his birth or minority he became also a subject of a foreign state, and not being under any disability, may divest himself of his British nationality by a declaration made under the provisions of the British Nationality and Status of Aliens Act, 1914, but such a declaration is ineffective during war, whether the declarant's foreign nationality is enemy or neutral, to relieve the declarant from liability to military service accrued before the declaration. And under the same Act, persons who, though born out of the king's dominions, are British subjects may (if not under disability) make a similar declaration without any such condition as to foreign nationality. Under the same Act a British subject who becomes a naturalised subject of a foreign state thereby divests himself of his British nationality. ${ }^{148}$

Phillips and Jackson (in 2001) noted:

A British subject of full age and capacity may under [the British Nationality Act 1981, s 12] renounce his British nationality. A declaration must be made in the prescribed form and registered by the Home Secretary if he is satisfied that after registration the person concerned will acquire some citizenship or nationality other than British citizenship. If another citizenship or nationality is not acquired within six months of registration the person shall be deemed to be and have remained a British citizen. It is provided, however, that the Home Secretary may withhold registration of any such declaration if made during any war in which [HM] may be engaged in right of [HM's] government in the $[\mathrm{UK}] .{ }^{149}$

\section{(b) Divestment of Nationality by Crown}

However, was there ever a Crown prerogative to divest a British subject of their nationality - that is, to alienate? On a general basis, there was. The Crown could divest subjects of their nationality by cession, with the result that they were, then, treated as aliens (for example, the citizens of Heligoland in 1890). Also, where the Crown was severed. ${ }^{150}$ Yet, it is unclear whether there was such a prerogative on an individual basis. Both Blackstone (in 1765-9) and Chitty (1820) do not appear to discuss divestment of nationality by virtue of the exercise of a Crown prerogative. That said, given that cession should (and is) only be effected today by virtue of legislation and not by way of Crown prerogative (see 10), it would seem appropriate to abolish any Crown prerogative to (forcibly) divest a British citizen of their nationality - such that such will only occur pursuant to legislation (in practice, this is likely to rarely occur anyway). ${ }^{151}$

\footnotetext{
${ }^{146}$ In order words, it seems clear that the law has invariably been (apart from where legislation provides otherwise) that British subjects are free to come and go from the realm.

${ }^{147}$ Chalmers (in 1922), n 15, pp 81, 83. He continued 'A person can also in some cases renounce British nationality by declaration of alienage; e.g. (1) an infant child of a foreign father, naturalised at the same time as its father and at his request, may do so on attaining majority; (2) A person who, though born out of [HM's] dominions, is deemed to be a natural-born British subject can make a declaration of alienage (apparently at any time after majority). (3) Where a convention to that effect exists between [HM] and a foreign State, persons of foreign parentage from that State who have become naturalised British subjects can renounce British natiuonality by declaration of alienage'.

${ }^{148}$ Ridges (in 1934), n 17, p 442.

${ }^{149}$ Phillips \& Jackson, n 30 (this article), p 510. It also noted 'Provision is made for resumption of citizenship by persons who have earlier renounced citizenship, for example a wife might have to renounce British citizenship under the law of her husband's state and wish to return to the [UK] on divorce or following his death.' See also British Nationality Act 1981, s 18.

${ }^{150}$ When the Crowns of two countries which have formerly been united are severed, allegiance automatically reverts to the place of birth. Thus, when William IV [1830-37] died, Hanovarians ceased to be British subjects. See Stepney Election petition (1892) 17 QBD 54. See also Ridges (in 1934), n 17, p 443 'On the separation of the kingdoms of the [UK] and Hanover, allegiance was held to have ceased [citing Isaacson $v$ Durant (1886) 17 QBD 54]. Similarly, on the successful revolt of the United States citizens of that country became aliens [citing Doe d Thomas v Acklam (1824) 2 B \& C 779], though British subjects who fought for the king and left the States remained British [Auchmuty v Mulcaster (1826) 5 B \& C 771].

${ }^{151}$ Withdrawing the passport of person prevents travel but does not, per se, remove nationality since passports (and letters of safe conduct) were, always, travel permits and no more.
} 


\section{(c) Conclusion}

Any Crown prerogative to divest a UK (British) person of their nationality should be abolished and this matter left to legislation. The same, it may be noted, should also apply to a British subject. Legislation should govern the matter and not the common law.

\section{In conclusion, any Crown prerogative to divest a UK citizen of their nationality should be abolished-this being left to legislation.}

\section{CROWN PREROGATIVES: RECOGNITION OF FOREIGN STATES}

(a) Background

Walker (1980) stated the general position as to the recognition of foreign states under international law:

In international law, any act on the part of one State which expresses or implies a legally significant reaction by it to the act of another state who does or may affect the legal rights or political interests of the first state. It is a political and executive act having legal consequences...A distinction is commonly drawn in relation to recognition of governments between de jure and de facto recognition; the difference is that de facto recognition takes place when a new authority has attained power, but has not attained such stability as to be apparently permanent or does not give prospects of being able to fulfil international obligations, whereas de jure recognition is recognition of the government which is lawfully entitled to exercise sovereignty, though it may not in fact do, but the effect of either depends very much on the facts and on the intention of the recognizing government. De facto recognition may not bring about diplomatic intercourse or conferment of diplomatic immunities on representatives. De jure recognition may follow de facto recognition if the new government appears to be firmly established and such that it should be acknowledged as the lawful authority. ${ }^{152}$

It is part of the Crown prerogative to recognise foreign states (countries) ${ }^{153}$ and the government thereof, whether de jure or de facto. It is unclear when the Crown first asserted this prerogative. More likely, there developed a government process in which the FCDO - to assist the courts - certified to the latter their position. Blackstone (1765-9) and Chitty (1820) did not mention the recognition by the Crown of foreign states. Nor did Halsbury $\left(1^{\text {st }}\right.$ edition in 1909). ${ }^{154}$ However, Wade (in 1931 stated):

It rests with the executive to decide whether or not recognition shall be accorded to a foreign government or State. The subject of recognition is one for international law, but the fact of recognition may have an important bearing on the result of litigation in which a British subject is engaged. In Duff Development Co v Government of Kelantan ${ }^{155}$ the House of Lords recognised that it had

for some time been the practice of the courts to take judicial notice of the sovereignty of a state and for that purpose (in any case of uncertainty) to seek information from a [SS]; and when such information is so obtained the court does not permit it to be questioned by the parties. See AM Luther $v$ J Sagor \& Co [1921] 3 KB 532.

Still more recently in Engelke v Musmann [1928] AC 433, a statement made to the court by the [A-G] on the instruction of the Foreign Office [FO] as to the status of a person claiming immunity from judicial process by reason of diplomatic immunity was accepted. The [FO] did not attempt here to interfere in the litigation; it merely furnished a record of what had been done by virtue of the prerogative in recognising the diplomatic status of one of the parties. The fact of recognition is peculiarly within the knowledge of the department [the FO] and is regarded by the courts as conclusive. ${ }^{156}$

This statement of Wade is important and it may have been forgotten by the courts in recent years. It is the English court which requests assistance from the government ministry which has best expertise in this matter, since this 'is peculiarly [i.e. especially] within the knowledge of such'. Thus, an English court should be (very) reluctant to challenge a FCDO certificate as not conclusive - unless it has very good reason. Otherwise, the court is, effectively, making a 'political' decision. And, such a result is not a good one since it involves the courts in political decisionmaking, to the loss to all. Wade continued:

But neither the executive of this country nor a foreign government can furnish the court with a statement which will be regarded as conclusive on the question of issues affecting the rights of subjects. In the Jupiter No 3 [1927] P 250, the court refused to accept a declaration as to past ownership of a ship by a foreign governemt, not the owner of the ship at the time of the action, and, therefore, not claiming immunity from jurisdiction. In a question between the Crown and a private person as to property a Minister of State cannot conclude the issue in favour of the Crown by a

\footnotetext{
${ }^{152}$ Walker, n 78, (recognition).

${ }^{153}$ The Foreign Jurisdiction Act 1890 s 16 defines a foreign country as 'any country or place out of [HM's] dominions.'

${ }^{154}$ Halsbury, Laws (1909), vol 6, pp 427-54. Cf. Keith, n 26 (this article), p 16 (in 1940) 'nor is there any [convention] regarding the consultation of the Commons before the grant of recognition to a foreign state or government de jure or de facto).'

${ }^{155}$ [1924] AC 797. See also Keith, n 26 (this article), p 129.

${ }^{156}$ Wade, n 16, pp 206-7.
} 
sworn declaration. Nor can the declaration of a foreign government be accepted as conclusive when a question as to property is litigated between private persons in the courts. ${ }^{157}$

Wade concluded:

The Crown can claim no prerogative, save such as the law allows; the courts, therefore, have jurisdiction to enquire into the existence and scope of any alleged prerogative. Accordingly, statements on behalf of the Crown are not conclusive as to the existence or extent of alleged prerogative power, so as to prejudice the rights of subjects. But where an act has been done by virtue of an undoubted prerogative, such as the recognition of a foreign state, the statement made by the government department concerned as to the exercise of the prerogative will be accepted as conclusive. ${ }^{158}$

Keith (in 1940) stated:

The Crown has unfettered power to recognise de facto or de jure foreign sovereigns, and the courts have accepted important results as being thence derived. If a state is recognised de facto, then the acts of sovereignty which it exercises in its territory, such as the confiscation of property, must be accepted by the courts. Further, in the case of Ethiopia it was held by the courts that it was possible for one sovereign to be recognised de facto and one de jure simultaneously, with the result that the latter could sue an English corporation for sums due in respect of a contract existing before the conquest of his country, but that his right to sue expired on the recognition de jure of the conquest. ${ }^{159}$

Also:

It lies with the executive government to make binding pronouncements on certain issues. Thus the courts will accept declarations as to the status of a foreign government and as to recognition or non-recognition of a foreign government ${ }^{160}$ or of [a] state of belligerency. They accept also any declaration as to whether any person is entitled to recognition as a diplomatic agent or a foreign sovereign, immune from British jurisdiction. The extent of the foreign jurisdiction of the Crown is by statute placed wholly within the control of the Crown, through the Foreign or Colonial Secretary. ${ }^{161}$ The extent of British territory proper is declared by the Crown through the Home Secretary. The existence and determination of a war are likewise so declared, though in the absence of any declaration on this or on the other points mentioned, the court might have to act on its own judgment. ${ }^{162}$

Phillips and Jackson (in 2001) stated:

The recognition by the Crown of foreign states, sovereigns and governments may affect the rights of private individuals because of the immunity, from the jurisdiction of the courts which such recognition confers, ${ }^{163}$ The court must accept the certificate of the Crown as to recognition, although it will examine the declaration in order to see that the proper facts have been considered by the appropriate ministers. Similar considerations apply to the recognition of diplomatic representatives, which confers diplomatic immunity. The decisions of the British courts in such cases illustrate according to Lord Wilberforce, the undoubted judicial acceptance of the principle that, 'In $a$ matter affecting the sovereignty of the [UK] the courts are entitled to take account of the declared policy of [HM's] government...the courts should in such matters speak with the same voice as the executive. ${ }^{164}$

Barnett (in 2020) stated:

The recognition of foreign states is within the prerogative of the Crown. ${ }^{165}$

\footnotetext{
${ }^{157}$ Ibid, p 207.

${ }^{158} \mathrm{Ibid}$. He continued 'This is true of declarations by the executive as to the beginning and end of a state of war is clear from Janson $v$ Driefontein Consolidated Mines [1902] AC (at p 500). In The Fagernes [1927] P 311, the Court of Appeal accepted the [AG's] statement, made on the instructions of the Home Secretary, that a place where a collision at sea had occurred was not claimed to be within the limits to which [HM's] jurisdiction extended. The collision occurred in the Bristol Channel several miles from the nearest land.'

${ }^{159}$ Keith, n 26 (this article), p 135. However, as Keith noted, there can be problems from de facto and de jure recognition be accorded to different parties (which courts should take note of) 'In the case of Spain the result of this doctrine was curious; it appeared that the courts would not exercise jurisdiction over either government, so that ships in the possession of the insurgents and ships in the possession of the recognised government were equally immune from jurisdiction.'

${ }^{160}$ Keith cited Duff Development Co v Govt of Kelantan [1924] AC 797 and The Gargara [1919] P 95.

${ }^{161}$ This refers to the Foreign Jurisdiction Act 1890 which Part 1 assets is now obsolete.

${ }^{162}$ Keith, n 26 (this article), pp 128-9.

${ }^{163}$ Phillips \& Jackson, $\mathrm{n} 30$ (this article), p 322. The authors cited Duff Development Co v Govt of Kelantan [1924] AC 797. In a fn, the authors stated 'The practice of recognising governments which have come to power by unconstitutional means was abandoned by the British government in 1980. Future certificates will merely indicate what links exist between the regime in question and HM government so, presumably, leaving the question of recognition to the courts: CR Symmons, 'United Kingdom abolition of the Doctrine of Recognition of Governments: A Rose by Another Name?' [1981] IL 249.'

${ }^{164} \mathrm{Ibid}, \mathrm{pp} 322-3$. The citation to Lord Wilberforce is Re Westinghouse Electric Corporation Uranium Contract Litigation MDL Docket no 235 [1978] AC 547, per Lord Wilberforce.

${ }^{165}$ Barnett, n 27, p 112. She referred, in a fn, to the Diplomatic Privileges Act 1964 (for this see 14). Also 'On immunities and privileges accorded to international and commonwealth organisations, see the International Organisations Acts 1968 and 1981; Diplomatic Immunities
} 


\section{(b) Conclusion}

To clarify matters, any Crown prerogative on the recognition of a foreign state should be abolished and legislation should deal with the process and nature of the certificate.

\section{In conclusion, a BTFRA should provide for the recognition of foreign states by the FCDO - and any Crown prerogative should be abolished.}

\section{DIPLOMATIC PRIVILEGE \& CONSULAR RELATIONS ACTS}

Various of legislation extant deal with diplomatic privileges and consular relations. They should be consolidated in a BTFRA (in a schedule) albeit some - such as that relating to consular fees - could be in a SI since there is no need for it to be in general legislation.

\section{(a) Diplomatic Privileges Act 1964}

This Act has the following sections extant:

1. (Replacement of existing law). The following provisions of this Act shall, with respect to the matters dealt with therein, have effect in substitution for any previous enactment or rule of law.

2. (Application of Vienna Convention). (1) Subject to [s] 3 of this Act, the Articles set out in [Sch] 1 to this Act (being Articles of the Vienna Convention on Diplomatic Relations signed in 1961) shall have the force of law in the [UK] and shall for that purpose be construed in accordance with the following provisions of this [s]. (2) In those Articles -"agents of the receiving State" shall be construed as including any constable and any person exercising a power of entry to any premises under any enactment (including any enactment of the Parliament of [NI]); "national of the receiving State" shall be construed as meaning citizen of the [UK] and colonies; "Ministry for Foreign Affairs or such other ministry as may be agreed" shall be construed as meaning the department of the [SS] concerned; and, in the application of those Articles to Scotland, any reference to attachment or execution shall be construed as a reference to the execution of diligence, and any reference to the execution of a judgment as a reference to the enforcement of a decree by diligence. (3) For the purposes of Article 32 a waiver by the head of the mission of any State or any person for the time being performing his functions shall be deemed to be a waiver by that State. (4) The exemption granted by Article 33 with respect to any services shall be deemed to except those services from any class of employment in respect of which contributions or premiums are payable under the enactments relating to... social security, including enactments in force in [NI], but not so as to render any person liable to any contribution or premium which he would not be required to pay if those services were not so excepted. (5) Articles 35, 36 and 40 shall be construed as granting any privilege or immunity which they require to be granted. (5A) The reference in Article 36 to customs duties shall be construed as including a reference to excise duties chargeable on goods imported into the [UK] and to [VAT] charged in accordance with [s] 10 or 15 of the Value Added Tax Act 1994 (acquisitions from other member States and importations from outside the [EU]). (6) The references in Articles 37 and 38 to the extent to which any privileges and immunities are admitted by the receiving State and to additional privileges and immunities that may be granted by the receiving State shall be construed as referring respectively to the extent to which any privileges and immunities may be specified by $[\mathrm{HM}]$ by $[\mathrm{OIC}]$ and to any additional privileges and immunities that may be so specified.

3.(Restriction of privileges and immunities). (1) If it appears to [HM] that the privileges and immunities accorded to a mission of $[\mathrm{HM}]$ in the territory of any State, or to persons connected with that mission, are less than those conferred by this Act on the mission of that State or on persons connected with that mission, $[\mathrm{HM}]$ may by an [OIC] withdraw such of the privileges and immunities so conferred from the mission of that State or from such persons connected with it as appears to [HM] to be proper. (2) An [OIC] under this [s] shall be disregarded for the purposes of [s] 50(4) of the British Nationality Act 1981 (circumstances in which certain persons entitled to exemption under [s] 8(3) of the Immigration Act 1971) are to be regarded for the purposes of [s]1(1) of the said Act of 1981 as settled in the [UK].

4. (Evidence). If in any proceedings any question arises whether or not any person is entitled to any privilege or immunity under this Act a certificate issued by or under the authority of the [SS] stating any fact relating to that question shall be conclusive evidence of that fact.

There are also sections on OIC (s 6) ${ }^{166}$ and savings (s 7). ${ }^{167}$

(Conferences with Commonwealth Countries and Commonwealth of Ireland) Acts 1952 and 1961 [rep]; International Headquarters and Defence Organisations Act 1964.' For these, see Part 1

${ }^{166}$ (Orders in Council). (1) No recommendation shall be made to [HM] in Council to make an Order under [s] 2 of this Act unless a draft thereof has been laid before Parliament and approved by resolution of each House of Parliament; and any [SI] containing an Order under [s] 3 of this Act shall be subject to annulment in pursuance of a resolution of either House of Parliament. (2) Any power to make an Order conferred by the foregoing provisions of this Act includes power to vary or revoke an Order by a subsequent Order.

167 7. (Saving for certain bilateral arrangements). (1) Where any special agreement or arrangement between the Government of any State and the Government of the [UK] in force at the commencement of this Act provides for extending - (a) such immunity from jurisdiction and from arrest or detention, and such inviolablility of residence, as are conferred by this Act on a diplomatic agent; or (b) such exemption from duties (whether of customs or excise) chargeable on imported goods, taxes and related charges as is conferred by this Act in respect of articles for the personal use of a diplomatic agent; to any class of person, or to articles for the personal use of any class of person, connected with the mission of that State, that immunity and inviolability or exemption shall so extend, so long as that agreement or arrangement continues in force. (2 ) The [SS] shall publish in the London, Edinburgh and Belfast Gazettes a notice specifying the States with which and the classes of person with respect to which such an agreement or arrangement as is mentioned in [ss] (1) of this [s] is in force and whether its effect is as 


\section{(b) Consular Relations Act 1968}

This Act deals with consular privileges and immunities. It has the following sections extant:

1. (Application of Vienna Convention). (1) Subject to [ss] 2 and 3(2) of this Act, the provisions set out in [Sch] 1 to this Act (being Articles or parts of Articles of the Vienna Convention on Consular Relations signed in 1963) shall have the force of law in the [UK] and shall for that purpose be construed in accordance with [ss] (2) to (11) of this [s].(2) In those provisions - "authorities of the receiving State" shall be construed as including any constable and any person exercising a power of entry to any premises under any enactment (including any enactment of the Parliament of [NI]); "grave crime" shall be construed as meaning any offence punishable (on a first conviction) with imprisonment for a term that may extend to five years or with a more severe sentence; "Ministry for Foreign Affairs" shall be construed as meaning the Department of the [SS] concerned; "national of the receiving State" shall be construed as meaning - (a) a British citizen, a British Dependent Territories citizen, a British National (Overseas)] or a British Overseas citizen; or (b) a person who under the British Nationality Act 1981 is a British subject; or (c) a British protected person (within the meaning of that Act). (3) The reference in [para] 2 of Article 17 to any privileges and immunities accorded by customary international law or by international agreements shall be construed as a reference to any privileges and immunities conferred under the International Organisations (Immunities and Privileges) Act 1950 or the International Organisations Act 1968. (4) The references in Article 44 to matters connected with the exercise of the functions of members of a consular post shall be construed as references to matters connected with the exercise of consular functions by consular officers or consular employees. (5) For the purposes of Article 45 and that Article as applied by Article 58 a waiver shall be deemed to have been expressed by a State if it has been expressed by the head, or any person for the time being performing the functions of head, of the diplomatic mission of that State or, if there is no such mission, of the consular post concerned. (6) The exemption granted by Article 48 with respect to any services shall be deemed to except those services from any class of employment in respect of which contributions or premiums are payable under the enactments relating to...social security, including enactments in force in [NI], but not so as to render any person liable to any contribution or premium which he would not be required to pay if those services were not so excepted. (7) Article 48 shall not affect any agreement made between the [UK] and any other State before the commencement of this Act and shall not be taken to prevent the making of any such agreement after the commencement of this Act. (8) Articles 50, $51,52,54,62$ and 67 shall be construed as granting any privilege or immunity which they require to be granted. (8A) The references in Articles 50 and 62 to customs duties shall be construed as including references to excise duties chargeable on goods imported into the [UK] and to [VAT] charged in accordance with [s] 10 or 15 of the Value Added Tax Act 1994 (acquisitions from other member States and importations from outside the European Union). (9) The reference in Article 57 to the privileges and immunities provided in Chapter II shall be construed as referring to those provided in Section II of that Chapter. (10) The reference in Article 70 to the rules of international law concerning diplomatic relations shall be construed as a reference to the provisions of the Diplomatic Privileges Act 1964. (11) The references in Article 71 to additional privileges and immunities that may be granted by the receiving State or to privileges and immunities so far as these are granted by the receiving State shall be construed as referring to such privileges and immunities as may be specified by [HM] by [OIC].

2. (Restriction of privileges and immunities).If it appears to[HM] that the privileges and immunities accorded to a consular post of the $[\mathrm{UK}]$ in a territory of any State, or to persons connected with such a consular post, are less than those conferred by this Act on a consular post of that State or on persons connected with such a consular post, [HM] may by [OIC] withdraw such of the privileges and immunities so conferred from all or any of the consular posts of that State or from such persons connected therewith as appears to $[\mathrm{HM}]$ to be proper.

3. (Agreements providing for additional or reduced privileges and immunities). (1) Where any agreement made, whether before or after the passing of this Act, between the [UK] and any other State provides for according to consular posts and persons connected with them privileges and immunities not accorded to them by the other provisions of this Act, [HM] may by [OIC] exercise, with respect to the consular posts of that State and persons connected with them, the powers specified in [Sch] 2 to this Act so far as may be necessary to give effect to that agreement. (2) Where any agreement made, whether before or after the passing of this Act, between the [UK] and any other State provides for according to consular posts and persons connected with them some but not all of the privileges and immunities accorded to them by the other provisions of this Act, [HM] may by [OIC] provide for excluding, with respect to consular posts of that State and persons connected with them, any of those privileges and immunities which are not provided for by the agreement.

mentioned in [para] (a) or [para] (b) of that [ss], and shall whenever necessary amend the notice by a further such notice; and the notice shall be conclusive evidence of the agreement or arrangement and the classes of person with respect to which it is in force. 
There are also sections dealing with ships and aircraft (ss $4^{168}, 5^{169}$ and 6). ${ }^{170}$ Also:

8. (Refund of customs duty on hydrocarbon oils). (1) The Treasury may authorise the [SS] or the Commissioners of Customs and Excise to make, if he or they think fit, arrangements for securing the refund of duty (whether of customs or excise) paid on imported hydrocarbon oil (within the meaning of the Hydrocarbon Oil Duties Act 1979) or [VAT] paid on the importation or acquisition from another member State of such oil which is - (a) bought in the [UK]; and (b) used for such purpose that, had it been imported for that use, exemption from duty thereon would have been required to be granted by virtue of Article 50 in [Sch] 1 to this Act or by virtue of an Order under [s] 3(1) of this Act ... (2) Any arrangements made under this [s] may impose conditions subject to which any refund is to be made. (3) Any amount refunded under arrangements made under this [s] shall be defrayed - (a) if the arrangements are made by the [SS] out of moneys provided by Parliament; and (b) if the arrangements are made by the Commissioners of Customs and Excise, out of the moneys standing to the credit of the General Account of the Commissioners of Customs and Excise.

10. (Right of diplomatic agents and consular officers to administer oaths and do notarial acts in certain cases).(1) A diplomatic agent or consular officer of any State may, if authorised to do so under the laws of that State, administer oaths, take affidavits and do notarial acts - (a) required by a person for use in that State or under the laws thereof; or (b) otherwise required by a national of that State but not for use in the [UK] except under the laws of some other country or (c) in connection with an international will. (2) $[\mathrm{HM}]$ may by $[\mathrm{OIC}]$ exclude or restrict the provisions of the preceding [ss] in relation to the diplomatic agents or consular officers of any State if it appears to Her that in any territory of that State diplomatic agents or consular officers of the [UK] are not permitted to perform functions corresponding in nature and extent to those authorised by that [ss]. (3) [HM] may by [OIC] make provision for applying [s] 6 of the Commissioners for Oaths Act 1889 (powers as to oaths and notarial acts abroad) to countries within the Commonwealth or the Republic of Ireland by requiring the [s] to be construed as if - (a) the references therein to a foreign country or place included such country or place as may be specified in the Order; and (b) the diplomatic ranks specified in that [s] included such ranks of any [UK] mission in a country specified in the Order as may be so specified in relation to that country. (4) In this [s] "diplomatic agent" has the same meaning as in the Diplomatic Privileges Act 1964 and "international will" has the meaning assigned to it by [s] 27 of the Administration of Justice Act 1982.

11. (Evidence). If in any proceedings any question arises whether or not any person is entitled to any privilege or immunity under this Act, a certificate issued by or under the authority of the [SS] stating any fact relating to that question shall be conclusive evidence of that fact.

\footnotetext{
168 4. (Civil jurisdiction concerning service on board ship or aircraft). [HM] may by [OIC] make provision for excluding or limiting the jurisdiction of any court in the [UK] to entertain proceedings relating to the remuneration or any contract of service of the master or commander or a member of the crew of any ship or aircraft belonging to a State specified in the Order, except where a consular officer of that State has been notified of the intention to invoke the jurisdiction of that court and has not objected within such time as may be specified by or under the Order.

${ }^{169}$ 5. (Jurisdiction over offences committed on board ship). (1) [HM] may by [OIC] make provision for securing that, where an offence is alleged to have been committed on board any ship by the master or a member of the crew and the ship belongs to a State specified in the Order, proceedings for the offence instituted otherwise than at the request or with the consent of a consular officer of that State are not entertained by any court in the [UK], unless - (a) the offence is alleged to have been committed by or against a person who is a citizen of the [UK] and colonies or is otherwise comprised in the definition of "national of the receiving State" in [s] 1(2) of this Act, or against a person other than the master or a member of the crew; or (b) the offence is one involving the tranquillity or safety of a port, or the law relating to safety of life at sea, public health, oil pollution, wireless telegraphy, immigration or customs or is of any other description specified in the Order; or (c) the offence is one comprised in the definition of "grave crime" in [s] 1(2) of this Act. (1A) In [ss] (1)(b) of this section the expression "the law relating to customs", to the extent that it refers to the law relating to duties on goods, refers to the law relating to duties (whether of customs or excise) for the time being chargeable on goods imported into the [UK]. (2) For the purposes of this [s] an offence which affects the property of any person shall be deemed to have been committed against him. (3) For the purposes of this [s], any document purporting to be signed by or on behalf of a consular officer and stating that he has requested or consented to the institution of any proceedings shall be sufficient proof of that fact unless the contrary is shown.

${ }^{170}$ 6. (Detention on board ship for disciplinary offences). [HM] may by [OIC] designate any State for the purposes of this [s]; and where a State is so designated, a member of the crew of a ship belonging to that State who is detained in custody on board for a disciplinary offence shall not be deemed to be unlawfully detained unless - (a) his detention is unlawful under the laws of that State or the conditions of detention are inhumane or unjustifiably severe; or (b) there is reasonable cause for believing that his life or liberty will be endangered for reasons of race, nationality, political opinion or religion, in any country to which the ship is likely to go.
} 
There are also sections dealing with privileges and immunities in connection with Commonwealth and Irish establishments, ${ }^{171}$ Commonwealth and Irish consular officers (s 13), ${ }^{172}$ OIC (s 14) ${ }^{173}$ and the validation of certain provisions in colonial laws (s 15). ${ }^{174}$

\section{(c) Diplomatic and other Privileges Act 1971}

\section{This Act has the following sections:}

1. (Refund of customs duty on hydrocarbon oil used for diplomatic or Commonwealth Secretariat purposes). (1) Subject to the provisions of this [s], the Commissioners of Customs and Excise shall make arrangements for securing the refund of duty (whether of customs or excise) paid on imported hydrocarbon oil (within the meaning of the Hydrocarbon Oil Duties Act 1979) or [VAT] paid on the importation of such oil which is - (a) bought in the [UK]; and (b) used for such a purpose that, had it been imported for that use, exemption from duty thereon would have been required to be granted by virtue of - (i) [para] 1 of Article 36 or [para] 1 of Article 37 of the Articles set out in [Sch] 1 to the Diplomatic Privileges Act 1964; or (ii) [s] 7 of the said Act of 1964; or (iii) [para] 4 of the [Sch] to the Commonwealth Secretariat Act 1966; but the Commissioners shall not make any payment by virtue of this [ss] before such date as may be specified by directions of the Treasury. (2) Any arrangements made under this [s] may impose conditions subject to which any refund is to be made. (3) [s] 3(1) of the said Act of 1964 (which relates to the withdrawal of privileges and immunities conferred by that Act) shall have effect as if the reference therein to that Act included a reference to this [s]. (4) Any amount refunded under arrangements made under this [s] shall be defrayed out of the moneys standing to the credit of the General Account of the Commissioners of Customs and Excise. (5) In this [s] references to importation, in relation to [VAT], shall include references to anything charged with tax in accordance with [s] 10 or 15 of the Value Added Tax Act 1994 ] (acquisitions from other member States and importations from outside the [EU]), and, in this [s], "imported" shall be construed accordingly. ${ }^{175}$

All of this legislation mentioned in (a)-(c) covers diplomatic privileges and it should be consolidated with other material referred to in Part 1. Thus, Phillips \& Jackson (in 2001) noted:

Under the International Organisations Acts 1968 and 1981 immunities and privileges may be accorded to international and Commonwealth organisations of which the [UK] is a member, and to persons connected with such organisations. Provision is also made for granting immunities and privileges to judges and suitors of the International Court of Justice, and to representatives of other states attending international conferences in the [UK]. Diplomatic privileges and immunities have been extended to the high commissioners or ambassadors of the independent members of the Commonwealth, Associated States and the Republic of Ireland, their staff, families and servants; and to certain representatives of Commonwealth governments and of the Government of the Republic of Ireland attending conferences with the British government. Diplomatic immunity and privileges may also be extended to [OIC] to any international headquarters or defence organisations set up under an arrangement for common defence, e.g. NATO, and the Visiting Forces Act 1952 and be applied to them. The privileges and immunities of consuls are

${ }^{171}$ 12. (1) [HM] may, in relation to any such Commonwealth representatives as are described in [ss] $n$ (2) below, provide by [OIC] for conferring all or any of the privileges and immunities which are conferred by or may be conferred under this Act on consular posts or persons connected with consular posts; and the reference in [s] 8(1)(b) of this Act (refund of hydrocarbon oil duty) to an order under [s] 3(1) of this Act shall extend also to an order under this [s. (2) The Commonwealth representatives in relation to whom this [s] applies are - (a) persons in the service of the Government of any country within the Commonwealth (other than the [UK] ) who hold offices appearing to [HM] to involve the performance of duties substantially corresponding to duties which, in the case of a foreign sovereign power, would be performed by a consular officer; and (b) any person for the time being recognised by [HM's] Government in the [UK] as the chief representative in the [UK] of a state or province of a country within the Commonwealth. (3) The privileges and immunities which may be conferred under this [s] shall include those which in other cases may, if an agreement so requires, be conferred by virtue of [Sch] 2 to this Act. (4) The provisions of this [s] shall have effect in relation to persons in the service of the Government of the Republic of Ireland as they have effect in relation to persons in the service of the Government of a country within the Commonwealth.

172 13. (Commonwealth and Irish consular officers). (1) If consular officers are appointed - (a) by [HM's] s Government in the [UK] to serve in any other country within the Commonwealth or in the Republic of Ireland; or (b) by the Government of any other country within the Commonwealth or of the Republic of Ireland to serve in the [UK]; any enactment passed before the passing of this Act which confers any function on consular officers shall be construed in accordance with the following provisions of this [s]. (2) References (however expressed) in any such enactment to a consular officer shall be construed, subject to any provision made under [ss] (3)(a) of this [s], as not including a consular officer appointed as mentioned in [ss] 1) (a) of this [s]. (3) [HM] may by [OIC] make provision -(a) for requiring references to a consular officer in any enactment passed before the passing of this Act to be construed as including a consular officer appointed as mentioned in[ss] (1)(a) of this [s] (or as including a consular officer so appointed in any country or place specified in the Order) or for the exercise by a consular officer so appointed (or so appointed in any such country or place) of any functions conferred by the enactment on some other officer; (b) for making in the Merchant Shipping Act 1995 or the Consular Conventions Act 1949 such adaptations of any provision referring to a consular officer of a foreign State as appear to Her to be necessary or expedient to make the provision applicable to consular officers appointed as mentioned in [ss] $(1)(b)$ of this [s] and to dispense with any requirement as to the conclusion of a consular convention.

173 14. (Orders in Council). (1) No recommendation shall be made to [HM] in Council to make an Order containing such provision as is mentioned in [s] 1(11) or [s] 3(1) of this Act unless a draft thereof has been laid before and approved by resolution of each House of Parliament. (2) Any other [SI] made under the foregoing provisions of this Act shall be subject to annulment in pursuance of a resolution of either House of Parliament. (3) Any power to make an Order conferred by this Act includes power to vary or revoke such an Order by a subsequent Order.

${ }^{174}$ This section would be repealed if the Colonial Laws Validity Act 1865 was repealed.

175 The other sections to this Act have been repealed or amend other Acts. 
governed by the Consular Relations Act 1968, which gives effect to the Vienna Convention on Consular Relations; and (as to Commonwealth and Irish consuls) by [s 4] of the Diplomatic and other Privileges Act 1971. ${ }^{176}$

\section{(d) Consular Conventions Act 1949 \& Consular Fees Act 1990}

The Consular Conventions Act 1949, s 1 makes provision on the powers of consuls in respect of the property in England of deceased persons. ${ }^{177}$ It states:

1. (Powers of consular officers in relation to property in England of deceased persons).(1) Where any person who is a national of a State to which this [s] applies is named as executor in the will of a deceased person disposing of property in England, or is otherwise a person to whom a grant of representation to the estate in England of a deceased person may be made, then if the court is satisfied, on the application of a consular officer of the said State, that the said national is not resident in England, and if no application for a grant of such representation is made by a person duly authorised by power of attorney to act for him in that behalf, the court shall make to that officer any such grant of representation to the estate of the deceased as would be made to him if he were so authorised as aforesaid: Provided that the court may, if it thinks fit, postpone the making of a grant by virtue of this [s] during such period as the court considers appropriate having regard to the circumstances of the case.

(2) Where any person who is a national of a State to which this [s] applies - (a) is entitled to payment or delivery of any money or property in respect of any interest in the estate of a deceased person, or vesting in possession on the death of any person, or is entitled to payment of any money becoming due on the death of any person; or (b) is a person to whom any money or property comprised in the estate of a deceased person may be paid or delivered in pursuance of any enactment, rule or regulation, whether passed or made before or after the commencement of this Act, authorising the payment or delivery of such money or property without representation to the estate of the deceased being granted, then if the said national is not resident in England, a consular officer of that State shall have the like right and power to receive and give a valid discharge for any such money or property in England as if he were duly authorised by power of attorney to act for him in that behalf: Provided that no person shall be authorised or required by this [ss] to pay or deliver any money or property to a consular officer if it is within his knowledge that any other person in England has been expressly authorised to receive that money or property on behalf of the said national.

(3) A grant of administration made by virtue of this [s] on may be made to the consular officer by his official title, and to his successors in office; and where a grant is so made, the office of administrator, and all the estate, rights, duties and liabilities of the administrator ...shall be vested in and imposed on the person for the time being holding the office, and no fresh grant shall be required by reason only of the death or vacation of office of the person to whom the grant was made or in whom it is vested as aforesaid: Provided that nothing in this [ss] shall affect any limitation contained in the grant, or any power of the court to revoke the grant.

(4) Notwithstanding anything in [ss] (2) of [s] 114 of the Senior Courts Act 1981 (which provides that in the case of a minority or a life interest administration must in general be granted either to a trust corporation or to not less than two individuals), administration of an estate may in any case be granted by virtue of this [s] to a consular officer alone; and [ss] (4) of that [a] (which provides for the appointment of additional personal representatives in the case of a minority or a life interest) shall not apply in any case where the existing personal representative is a consular officer appointed by virtue of this [s]

\footnotetext{
${ }^{176}$ Phillips \& Jackson, n 30 (this article), pp 331-2.

${ }^{177}$ 1. (Powers of consular officers in relation to property in England of deceased persons).(1)Where any person who is a national of a State to which this [s] applies is named as executor in the will of a deceased person disposing of property in England, or is otherwise a person to whom a grant of representation to the estate in England of a deceased person may be made, then if the court is satisfied, on the application of a consular officer of the said State, that the said national is not resident in England, and if no application for a grant of such representation is made by a person duly authorised by power of attorney to act for him in that behalf, the court shall make to that officer any such grant of representation to the estate of the deceased as would be made to him if he were so authorised as aforesaid: Provided that the court may, if it thinks fit, postpone the making of a grant by virtue of this [s] during such period as the court considers appropriate having regard to the circumstances of the case. (2) Where any person who is a national of a State to which this [s] applies - (a) is entitled to payment or delivery of any money or property in respect of any interest in the estate of a deceased person, or vesting in possession on the death of any person, or is entitled to payment of any money becoming due on the death of any person; or (b) is a person to whom any money or property comprised in the estate of a deceased person may be paid or delivered in pursuance of any enactment, rule or regulation, whether passed or made before or after the commencement of this Act, authorising the payment or delivery of such money or property without representation to the estate of the deceased being granted, then if the said national is not resident in England, a consular officer of that State shall have the like right and power to receive and give a valid discharge for any such money or property in England as if he were duly authorised by power of attorney to act for him in that behalf: Provided that no person shall be authorised or required by this subsection to pay or deliver any money or property to a consular officer if it is within his knowledge that any other person in England has been expressly authorised to receive that money or property on behalf of the said national. (3) A grant of administration made by virtue of this [s] on may be made to the consular officer by his official title, and to his successors in office; and where a grant is so made, the office of administrator, and all the estate, rights, duties and liabilities of the administrator ...shall be vested in and imposed on the person for the time being holding the office, and no fresh grant shall be required by reason only of the death or vacation of office of the person to whom the grant was made or in whom it is vested as aforesaid: Provided that nothing in this [ss] shall affect any limitation contained in the grant, or any power of the court to revoke the grant. (4) Notwithstanding anything in [ss] (2) of [s] 114 of the Senior Courts Act 1981 (which provides that in the case of a minority or a life interest administration must in general]be granted either to a trust corporation or to not less than two individuals), administration of an estate may in any case be granted by virtue of this [s] to a consular officer alone; and [ss] (4) of that [s] (which provides for the appointment of additional personal representatives in the case of a minority or a life interest) shall not apply in any case where the existing personal representative is a consular officer appointed by virtue of this [s].
} 
There are, also, sections dealing with powers of consular officers in relation to property in Scotland of deceased persons (s 2), supplementary provisions (s 3 ) and application provisions (ss $6 \&$ 7). There is also the Consular Fees Act 1990, s 1 which provides for consular fees.

\section{(e) Crown Agents Act 1995}

As Walker (in 1980) noted, Crown agents were the commercial and financial agents in the UK of BOT which did not have a representative government. ${ }^{178}$ First established under the Royal prerogative in 1833 as 'Joint Agents General for the Crown Colonies', they continued as such (without a statutory authority or formal constitution) until the Crown Agents Act 1979, which Act was superceded by the Crown Agents Act 1995. It has the following extant sections:

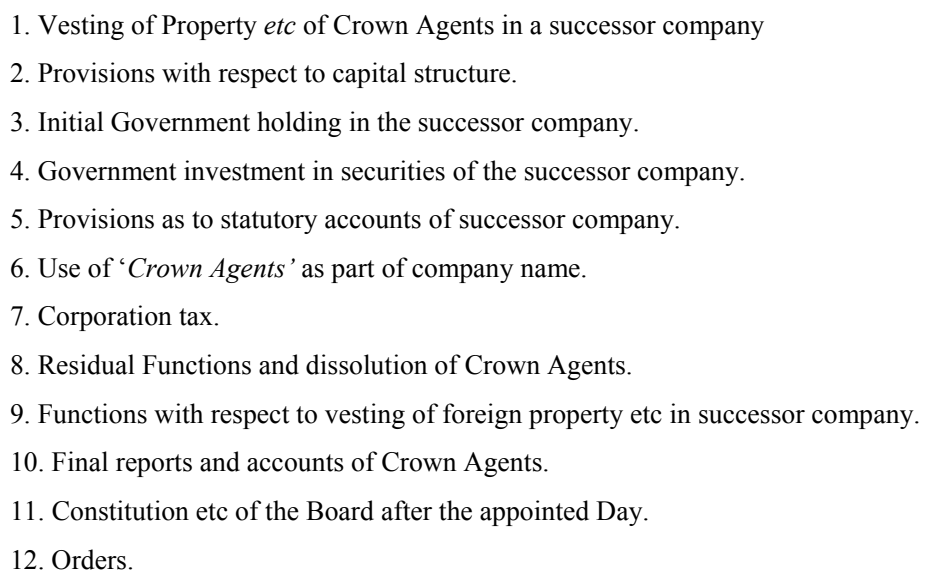

11. Constitution etc of the Board after the appointed Day.

12. Orders

It seems likely that some (or all) of this Act is not required.

\section{(f) State Immunity Act 1978}

This Act contains the following sections:

1. General immunity from jurisdiction.

2. Submission to jurisdiction.

3. Commercial transactions and contracts to be performed in UK

4. Contracts of employment.

5. Personal injuries and damage to property.

6. Ownership, possession and use of property.

7. Patents, trade-marks etc.

8. Membership of bodies corporate etc.

9. Arbitrations.

10. Ships used for commercial purposes.

11. Value added tax, customs duties etc.

12. Service of process and judgments in default of appearance.

13. Other procedural privileges.

14. States entitled to immunities and privileges.

15. Restriction and extension of immunities and privileges.

16. Excluded matters.

17. Interpretation of Part I.

18. Recognition of judgments against UK.

19. Exceptions to recognition.

20. Heads of State.

21. Evidence by certificate.

22. General interpretation.

23. Short title, repeals, commencement and extent.

\footnotetext{
${ }^{178}$ Walker, n 78 (Crown Agents) 'The commercial and financial agents in the UK of colonies which do not have representative government and of protectorates.
} 
This Act should be consolidated in a BTFRA (as with the other legislation referred to, it is not suggested that the same be fundamentally reviewed, consolidation only is necessary).

In conclusion, all the above legislation should be consolidated in an appendix to a BTFRA - to the extent the same is still required - and it cannot otherwise be placed in a SI.

\section{CONCLUSION}

The conclusion to this article may be stated simply:

- Legislation relating to diplomatic privileges, consular conventions, Crown agents and State immunity (see 14) should be consolidated in a BTFRA, to the extent still required;

- Various Crown prerogatives relating to foreign relations should be placed in a BTFRA. This is because they are, at common law, obscure and out of date. Further, they are based on the legal fiction that the Crown (whether the sovereign in person or the sovereign in the body politic) is performing certain acts of foreign policy when, in fact, the same is performed by government ministers and civil servants who are accountable (answerable) to Parliament. ${ }^{179}$

Thus, Crown prerogatives dealing with the following should be placed in a BTFRA:

- Diplomacy;

- Treaties;

- UK Ambassadors and other diplomats;

- Diplomatic privileges;

- $\quad$ Foreign Diplomats - Accreditation \& Dismissal;

- Acquisition of Foreign Territory;

- Cession of UK territory;

- Denization of Aliens; (obs)

- Naturalisation of Aliens (confirming that no Crown prerogative exists);

- Passports;

- Divestment (Renunciation) of Nationality;

- Recognition of Foreign States.

Proposed sections (which would be added to the BTFRA in Appendix A to Part 1 of this article) are set out in Appendix 1 hereto. Would any of the above be difficult? It is asserted the answer is ' $n o$ '. Would any of the above be contentious? One would suggest not. It is patently obvious that the sovereign is not (and should not) be personally involved in any of the above, and that the FCDO can (and should) deal with such matters. It would also seem appropriate that any acquisition of foreign territory (or cession of UK territory) - rare as it now is - should be dealt with by Act of Parliament. It would also be (exceedingly) useful to consolidate legislation relating to foreign affairs, to make the same more coherent and accessible.

\section{Appendix 1 - BRITISH TERRITORIES AND FOREIGN RELATIONS ACT}

An Act to consolidate various constitutional matters relating to British territories and to foreign affairs.

\section{Contents}

Parts 1-3

$\underline{\text { Part } 4}$

Diplomacy

30. Conduct of UK Diplomacy

31. UK Diplomats

32. Foreign Diplomats: Responsibility

33. Foreign Diplomats: Dismissal

34. Diplomatic Privileges

35. Treaty Making

$\underline{\text { Passports }}$

36. UK Passports

$\underline{\text { UK Nationality }}$

37. Denization

\footnotetext{
${ }^{179}$ Bradley, n 26, p 242 'It is still formally the case that executive power in the [UK] is vested in the Crown, however little this may reflect the reality of modern government. The Queen may reign, but it is the $[\mathrm{PM}]$ and other ministers who rule.'
} 
38. Naturalisation

39. Divestment and Renunciation

Territory

40. Acquisition of Foreign Territory

41. Cessation of UK Territory

Foreign States

30. Conduct of UK Diplomacy

42. Recognition

(1) The FCDO is responsible for the conduct of the UK's foreign relations (foreign diplomacy):

(a) in particular, for the matters outlined in ss 31-5,

(b) save where legislation provides otherwise.

(2) Any Crown prerogative to conduct the UK's foreign relations is abolished.

\section{UK Diplomats}

(1) The FCDO is responsible for the employment of all UK:

(a) ambassadors;

(b) consuls; and

(c) other officers performing a diplomatic role (together, 'UK Diplomats')

(2) The FCDO shall:

(a) appoint;

(b) dismiss; or

(c) accept the resignation of:

a UK Diplomat pursuant to a formal letter issued by the FCDO, signed by:

(i) the Foreign Minister (or any designate); or the

(ii) head of the FCDO (or any designate).

(3) A letter issued pursuant to (2) is conclusive of the same for all legal purposes, save in the case of manifest error.

(4) Any Crown prerogative in respect of UK diplomats is abolished.

\section{Foreign Diplomats: Responsibility}

(1) The FCDO is responsible for the appointment in the UK of all foreign:

(a) ambassadors;

(b) consuls; and

(c) other officers performing a diplomatic role (together 'Foreign Diplomats').

(2) The FCDO shall:
(a) appoint
(b) dismiss; or
(c) accept the resignation of:

a Foreign Diplomat pursuant to a formal letter issued by the FCDO, signed by the:

(i) Foreign Minister (or any designate); or

(ii) head of the FCDO (or any designate).

(3) A letter issued pursuant to (2) is conclusive of the same for all legal purposes, save in the case of manifest error. ${ }^{180}$

(4) Any Crown prerogative in respect of Foreign Diplomats is abolished.

\section{Foreign Diplomats: Dismissal}

(1) A Foreign Diplomat may not be appointed, or shall have his (or her) appointment removed, by the FCDO if the same:

(a) has committed (or commits) any serious criminal offence under UK law;

(b) is a member (or becomes such) of any proscribed criminal or terrorist organisation; ${ }^{181}$

(c) has been convicted (or is convicted) by any court of law in any designated country of:

(i) drug trafficking;

\footnotetext{
${ }^{180}$ See Keith (this article), p 129 'The [courts] accept also any declaration as to whether any person is entitled to recognition as a [foreign] diplomatic agent ... immune from British jurisdiction.'

${ }^{181}$ Legislation (or a SI) should list proscribed criminal organisations (mafia etc) as well as terrorist organisations.
} 

(ii) terrorism;
(iii) people trafficking;
(iv) prostitution;
(v) money laundering;
(vi) slave trading;
(vii) genocide.

(d) is (or becomes) a family member of the leader of any country:

(i) on a UK sanctions list;

(ii) designated by the UK as being governed by a civil or military dictatorship.

(e) is a former Head of State or President or Vice-President.

\section{Diplomatic Privileges}

(1) Appendix 1, Part A shall apply in respect of diplomatic privileges. ${ }^{182}$

(2) Appendix 1, Part B shall apply to consular handling of the estates of deceased persons. ${ }^{183}$

(3) Appendix 1, Part C shall apply to state immunity.

(4) Any Crown prerogative in respect of diplomatic privileges is abolished.

(5) The legislation in Appendix 1, Part D is repealed.

\section{Treaty Making}

(1) The FCDO is responsible for the making of treaties between the UK and foreign countries: ${ }^{184}$

(a) save where a SI designates

(b) the Cabinet or another Ministry.

(2) A treaty shall be executed by the same being signed by the FCDO minister (or other minister in accordance with (1)).

(3) [Ratification of Treaties. This will set out the Constitutional Reform and Governance Act 2010, ss 20-5] ${ }^{185}$

(4) No treaty that has been ratified shall have effect under UK domestic law unless the same is contained in an:

(a) Act of Parliament; or a

(b) SI.

(5) The following matters are not justiciable: the political decision whether to:

(a) make;

(b) ratify; or

(c) denounce, a treaty (or not).

(6) Any Crown prerogative in respect of the making of treaties is abolished.

(7) Any requirement for a treaty to be executed by means of the Great Seal of the UK is abolished.

(8) The term 'treaty' shall be as defined in the Vienna Convention on the Law of Treaties 1969. ${ }^{186}$

\section{UK Passports}

(1) The HM Passport Office (the 'PO') is responsible for the:
(a) issue (or not);
(b) revocation; ${ }^{187}$ and
(c) impounding,

of UK passports.

(2) Every qualified person ('Qualified Person') is entitled to legally require the PO:188
(a) to issue him (or her) with a passport,
(b) on payment of the requisite fee.

(3) A Qualified Person is one;

\footnotetext{
182 This will consolidate the material in $\mathbf{1 4}$.

${ }^{183} \mathrm{Ibid}$. It is unclear why this is in general legislation. It would seem fit for a SI.

${ }^{184}$ This is presently defined in the Foreign Jurisdiction Act 1890, s 16, see n 152

${ }^{185}$ See McBain, n 1 (Parliament), p 180.

${ }^{186}$ This definition is wide. Thus, a more limited definition may be required.

${ }^{187}$ Another word is 'withdrawl'.

${ }^{188}$ De Smith, n 23, p 422, n 90 'Justice, Going Abroad: A Report on Passports (1975)...recommends the enactment of a statute conferring upon all citizens the legal right to a passport.'
} 
(a) over the age of [16]:;89

(b) who is a UK citizen (including by way of naturalisation) ('UK Citizen'). ${ }^{190}$

(4) The PO shall revoke, and impound, a UK passport when:

(a) the same has been obtained by any criminal act under UK law; or

(b) legislation provides for such; ${ }^{191}$ or

(c) a UK court so orders. ${ }^{192}$

(5) A criminal act (wherever committed) includes where a UK passport has been obtained by the holder by:

(a) theft;

(b) fraud; ${ }^{193}$

(c) misrepresentation;

(d) failing to disclose to the PA facts which materially affect treating that person as a qualified person in (3)

(6) Any Crown prerogative with respect to UK passports, is abolished.

(7) UK Citizen means: [ ] ${ }^{194}$

(8) UK passports are the property of the PO.

\section{Denization}

(1) The Crown prerogative to make an alien a denizen is abolished.

\section{Naturalisation}

(1) There was (and is) no Crown prerogative to naturalise an alien.

\section{Divestment and Renunciation}

(1) A UK Citizen may only be divested of UK citizenship according to legislation.

(2) Any Crown prerogative with respect to the divestment of UK citizenship is abolished.

(3) A UK Citizen may only renounce their nationality according to legislation.

\section{Acquisition of Foreign Territory}

(1) No foreign territory may be acquired by the UK, including by way of:
(a) annexation,
(b) cession,
(c) protectorate, or
(d) mandate,

unless by an Act of Parliament.

(2) Any Crown prerogative in respect of (1) is abolished.

\section{Cessation of UK Territory}

(1) No UK territory may be:
(a) ceded; or
(b) given up

\footnotetext{
${ }^{189}$ An exception could be provided, cf. Phillips \& Jackson (this article), n 30, p 507 'The Home Secretary is given a discretion to register minors as British citizens by s 3 [of the British Nationality Act 1948] which spells out particular requirements to be satisfied in specific types of application.'

${ }^{190}$ Is the expression 'British subject' or 'British citizen' now required? Cf. Chalmers (in 1922), n 15, p 80 which defined British subjects as (a) natural born; (b) naturalised; (c) have acquired British nationality owing to a British conquest or cession of territory to Great Britain or, if a woman, by marrying a British subject. Under the British Nationality Act 1981, three categories of citizenship were recognised: (a) British citizen; (b) British Dependent Territories citizen (now BOT); (c) British Overseas citizen. Also, the special status of (d) British protected persons; (e) British subjects without citizenship (British Subjects). The Hong Kong Act 1985 created a further category of British National (Overseas). The only category with a right of abode in the UK was (a). However, all this simply creates confusion. It would seem better to create one category 'UK citizen' with sub-categories and specify which has a right of abode. Further, the category of 'protected person' would no longer seem necessary. In any case, if any protected person holds another passport, the UK passport should be revoked.

${ }^{191}$ See British Nationality Act 1948, s 40.

192 This refers to the writ ne exeat regno when the same became transmuted into a power of a court to prohibit a person from leaving the realm, McBain, n 120 (this article), p 30. The two are not the same. One was a State writ, the other akin to an injunction, part of the inherent power of the court.

${ }^{193}$ Phillips \& Jackson, n 30 (this article), p 509 'An applicant whose right to be registered depends on her own antecedent fraud is not entitled to challenge the [SS's] refusal to register her as a British citizen: $R v$ [SS] for the Home Department, ex p Puttick [1981] 1 QB 767.

${ }^{194}$ It is likely that new legislation will deal with nationality, repealing the British Nationality Act 1981. Thus, any definition should dovetail with the same.
} 
unless by an Act of Parliament.

(2) Any Crown prerogative in respect of (1) is abolished.

\section{Recognition of Foreign States}

(1) The FCDO is responsible for the recognition by the UK of any foreign state.

(2) The FCDO shall issue a certificate of recognition, if required by a UK court of law, which shall be conclusive of the same for all legal purposes, save in the case of manifest error.

(3) The certificate shall indicate whether:

(a) a foreign state and/or government (or asserted government) is

(b) recognised by the UK;

(i) de jure; and/or

(ii) de facto.

(4) The certificate shall be signed by the:

(i) Foreign Minister (or any designate); or

(ii) head of the FCDO (or any designate).

(5) Any Crown prerogative to issue a certificate is abolished.

Appendix 1, Part A - Consolidates - Diplomatic Privileges Act 1964, Consular Relations Act 1968, Diplomatic and other Privileges Act 1971 and the Diplomatic and Consular Premises Act 1987, see 14.

Appendix 1, Part B - Consolidates the Consular Conventions Act 1949

Appendix 1, Part C - Consolidates the State Immunity Act 1978

Appendix 1, Part D - Repeals the above and the Consular Fees Act 1900 (which should become a SI).

\section{Copyright}

Copyright for this article is retained by the author(s), with first publication rights granted to the journal.

This is an open-access article distributed under the terms and conditions of the Creative Commons Attribution license (http://creativecommons.org/licenses/by/4.0/). 